PNNL-11591

UC-510

\title{
Frit Screening for Rocky Flats Ash and Sand, Slag, and Crucible Vitrification
}

June 1997

RECEIVED

JUL 211997

O STI

Prepared for the U.S. Department of Energy under Contract DE-AC06-76RLO 1830

Pacific Northwest National Laboratory

Operated for the U.S. Department of Energy

by Battelle 


\section{DISCLAIMER}

This report was prepared as an account of work sponsored by an agency of the United States Government. Neither the United States Government nor any agency thereof, nor Battelle Memorial Institute, nor any of their employees, makes any wirranty, express or implied, or assumes any legal liability or responsibility for the accuracy, completeness, or usefulness of any information, apparatus, product, or process disclosed, or represents that its use would not infringe privately owned rights Reference herein to any specific commercial product, process, or service by trale name, trademark, manufacturer, or otherwise does not necessarily constitute or imply its endorsement, recommendation, or favoring by the United State; Government or any agency thereof, or Battelle Memorial Institute. The views and opinions of authors expressed herein do not necessarily state or reflect thlose of the United States Government or any agency thereof.

\section{PACIFIC NORTHWEST NATIONAL LABORATORY operated by \\ BATTELLE for the}

UNITED STATES DEPARTMENT OF ENERGY under Contract DE-AC06-76RLO 1830 
PNNL-11591

UC-510

Frit Screening for Rocky Flats Ash and Sand, Slag, and Crucible Vitrification

John D. Vienna, Hong Li, John G. Darab, Pavel Hrma, Ja-Kael Luey, and Michael L. Elliott Pacific Northwest National Laboratory, Richland, WA 99352

June 1997

Prepared for the U.S. Department of Energy

under Contract DE-AC06-76RLO 1830

Pacific Northwest National Laboratory

Richland, Washington 99352 


\section{DISCLAMver}

Portions of this docoment may be illegible in electronic image products. Images are produced from the best available original doemenert 


\section{SUMMARY}

The Pacific Northwest National Laboratory (PNNL) is supporting the efforts of Safe Sites of Colorado to develop a vitrified waste form for Rocky Flats Environmental Technology Site (RFETS) waste material. Specifically, PNNL is developing waste forms for plutonium-bearing ash and plutonium-bearing sand, slag, and crucible (SS\&C) materials. Waste forms are to be developed to meet both applicable product criteria (e.g., safeguard termination limits, storage criteria, and target plutonium loading) and processing constraints (e.g., upper temperature limits, processing time, and equipment compatibility). The target waste form for ash is an agglomerated product, while that for SS\&C is a fully encapsulated product.

Laboratory scoping studies were conducted on glass formulations from six different glass families: 1) antimony vanadium phosphate, 2) iron vanadium phosphate, 3) tin zinc phosphate, 4) soda-lime silicate, 5) alkali borosilicate, and 6) alkali borate. These glass families were selected due to their viscosity behavior in the temperature range of interest $\left(<800^{\circ} \mathrm{C}\right)$. Data from literature and glass property databases were used to calculate initial glass compositions and composition variations for the scoping studies performed. Each of these glass families have unique properties and characteristics that make them particularly useful for processing ash material.

Tests performed during scoping studies included gradient furnace tests to determine processing range and sintering temperature, thermogravimetric analysis to determine weight loss as a function of temperature, and crucible tests to determine robustness of a frit compositions (or tolerance to variations in processing temperature, waste loading, and waste type).

The primary screening criterion for the down selection of frits for future studies was processing temperature. Processing below $400^{\circ} \mathrm{C}$ was desired to minimize the potential for foaming in ash caused by the release of gases (main source of gas is combustion of carbon species) and to minimize processing cycle times. Based on this criterion, glass formulations from the tin zinc phosphate and alkali borosilicate glass families were selected for future variability testing. Variability testing will include evaluation of final product, tolerance of glass system to waste loading and composition variation, and identification of parameters impacting time/temperature profiles. Results from variability testing will give a final frit formulation for ash and SS\&C, as well as the identification of key processing parameters. 


\section{CONTENTS}

SUMMARY $\ldots \ldots \ldots \ldots \ldots \ldots \ldots \ldots \ldots \ldots \ldots \ldots \ldots \ldots \ldots \ldots$

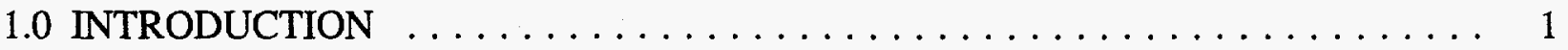

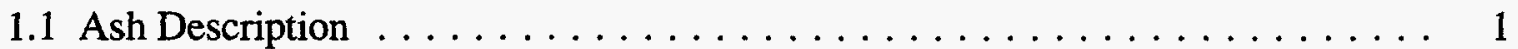

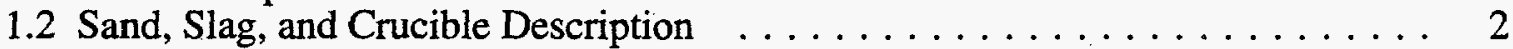

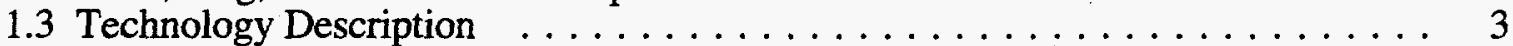

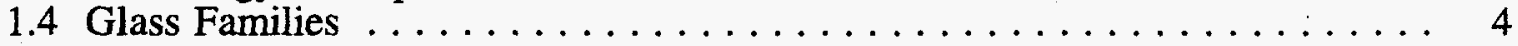

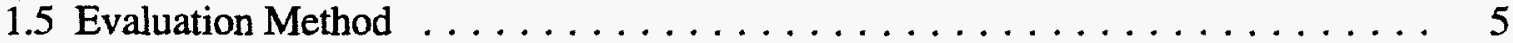

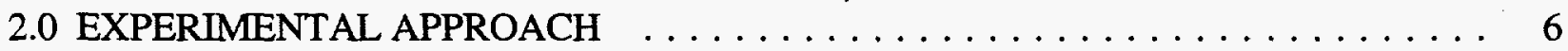

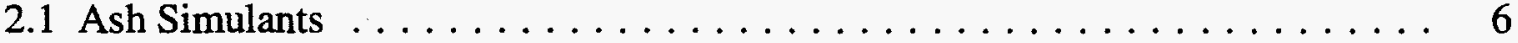

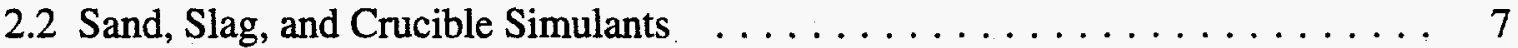

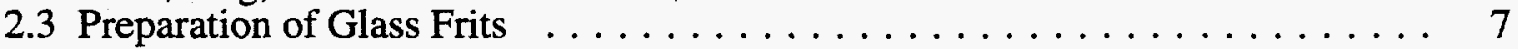

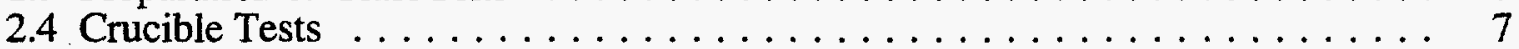

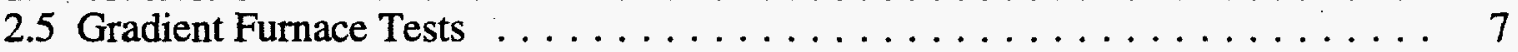

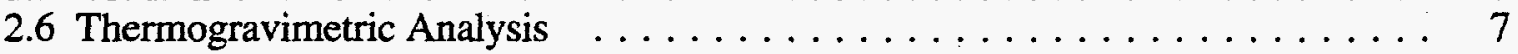

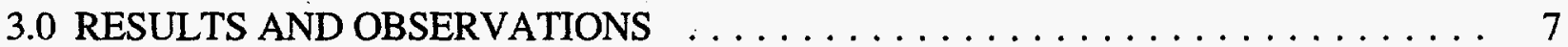

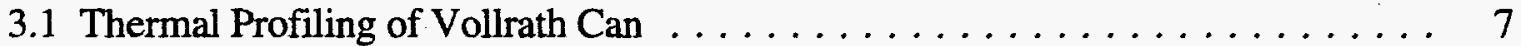

3.2 Thermogravimetric Analysis of Ash Simulants $\ldots \ldots \ldots \ldots \ldots \ldots \ldots$

3.3 Antimony Vanadium Phosphate Frit $\ldots \ldots \ldots \ldots \ldots \ldots$

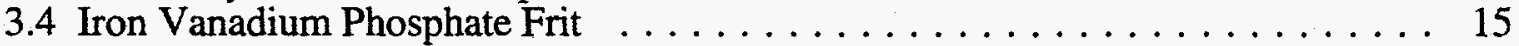

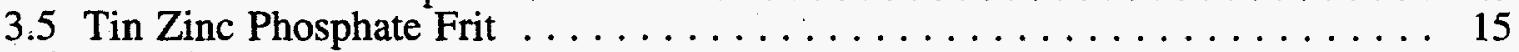

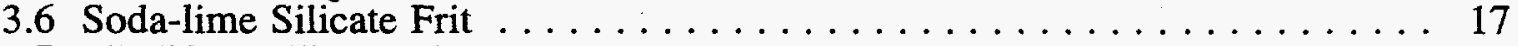

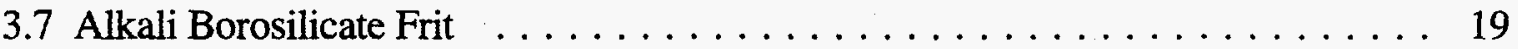

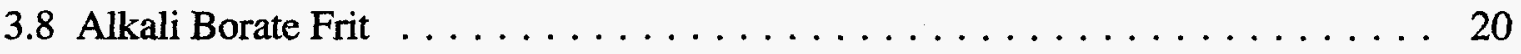

4.0 DISCUSSION AND RECOMMENDATION $\ldots \ldots \ldots \ldots \ldots \ldots \ldots \ldots$

5.0 ACKNOWLEDGMENTS $\ldots \ldots \ldots \ldots \ldots \ldots \ldots \ldots \ldots \ldots \ldots \ldots$

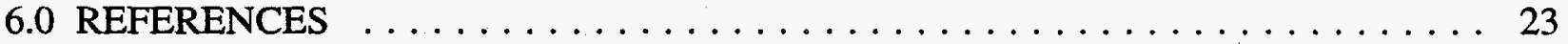

7.0 APPENDIX - Full-Scale Vollrath Container Test with PNNL Black Frit $\ldots \ldots$. . 24 


\subsection{INTRODUCTION}

The ash residue bucket at Rocky Flats Environmental Technology Site (RFETS) consists of approximately $27,900 \mathrm{~kg}$ of material from various sources. The majority of this material $(19,700$ $\mathrm{kg}$ ) is ash from incineration of combustibles for plutonium recovery. Also included are $6,700 \mathrm{~kg}$ of sand, slag, and crucible (SS\&C) residue generated from the bomb reduction of $\mathrm{PuF}_{4}$ and $\mathrm{PuO}_{2}$ to Pu metal. The approximately $1,500 \mathrm{~kg}$ that remain consist of firebrick from the incinerator, graphite fines scarfed from foundry molds, Leco crucibles, and miscellaneous inorganics.

The ash bucket materials must be treated for safe storage and disposal in the Waste Isolation Pilot Plant (WIPP). A set of criteria for the final treated waste forms is being developed by RFETS to address concerns of safe storage [1], safeguards termination [2], WIPP waste acceptance [3], and Department of Transportation regulations. The SS\&C and ash must be treated by 1998 and 2002, respectively, in existing RFETS facilities. To meet this aggressive schedule, equipment modifications, cycle times, and process upsets must be minimized. Vitrification was chosen as the baseline technology for ash and as a backup technology for SS\&C because of the increasing probability that it can economically meet the product criteria within the process schedule. The baseline technology for SS\&C is aqueous separation of Pu.

The vitrification technology discussed in this report is a low-temperature agglomeration/ encapsulation process being developed by a multi-site team [Pacific Northwest National Laboratory (PNNLa), Los Alamos National Laboratory (LANL), and Safe Sites of Colorado (SSOC) at RFETS]. Ash or SS\&C will be mixed with glass frit in appropriate proportions to maintain adequate concentrations of $\mathrm{Pu}$ for termination of safeguards while ensuring that the full 200 fissile gram equivalent (FGE) (minus twice the measurement uncertainty) is loaded in each transuranic (TRU) waste drum. The primary container for the waste form will be an 8 inch diam. by 10 inch tall steel Vollrath can. The waste form will be batch-vitrified in a muffle furnace for $4 \mathrm{~h}$ at a temperature below $800^{\circ} \mathrm{C}$. Two cans will be sealed in a Rocky Flats' pipe component inside a 55gal TRU waste drum and stored for eventual disposal in WIPP.

The high carbon and/or organic content and fine particle size of ash (compared to SS\&C) make agglomeration/encapsulation more difficult than SS\&C. In ash, decomposition of organics and loss of water at low temperatures $\left(\leq 250^{\circ} \mathrm{C}\right)$ and oxidation of carbon at higher temperatures $\left(400^{\circ} \mathrm{C}\right.$ to $600^{\circ} \mathrm{C}$ ) can cause foaming while processing with viscous glass. The small particle size of ash assists in ash-frit surface reaction and inhibiting frit contact, further complicating the encapsulation process. Ash vitrification is the thus primary focus of this study. The appropriate glass frit composition for encapsulation of SS\&C will follow directly from the study of ash encapsulation.

The objective of this report is to present and evaluate data on glass frit compositions being considered for use in the vitrification of RFETS ash and SS\&C. Following the description of the encapsulation process and preliminary data, a discussion of each glass family will lead to a recommendation on a glass to be further studied for encapsulation of RFETS ash and SS\&C.

\subsection{Ash Description}

Ash was generated by the incineration of plutonium-bearing organics at RFETS. The furnaces were small (for safety) and operated at low temperatures (nominally $200^{\circ} \mathrm{C}$ to $900^{\circ} \mathrm{C}$ ) to facilitate $\mathrm{Pu}$ recovery processes. This incineration process led to incomplete combustion of the organics. 
The composition range frequently reported by RFETS for these ash materials is given in Table I. Although reported analyses of ashes differ significantly from this range, it is speculatedb that this range is applicable to most of the ash stored in backlog. Ash is highly variable in composition with nearly an order of magnitude variation in $\mathrm{SiO}_{2}, \mathrm{~B}_{2} \mathrm{O}_{3}, \mathrm{Fe}_{2} \mathrm{O}_{3}$, and $\mathrm{Na} 2 \mathrm{O}$ and half an order of magnitude variation in $\mathrm{Al}_{2} \mathrm{O}_{2}, \mathrm{CaO}, \mathrm{MgO}$, and $\mathrm{C}$. The carbon/organic content is high, ranging up to $36 \mathrm{wt} \%$.

Table I. Rocky Flats ash composition range (wt\% reported as oxides, C, Cl, and F) [4]

\begin{tabular}{||c|c|c|c|c|c|c|c||}
\hline & $\min$ & $\max$ & average & & $\min$ & $\max$ & average \\
\hline $\mathrm{Al}_{2} \mathrm{O}_{3}$ & 0.95 & 5.7 & 3.33 & $\mathrm{NiO}$ & 0.25 & 0.64 & 0.45 \\
\hline $\mathrm{Am}_{2} \mathrm{O}_{3}$ & 0.02 & 0.02 & 0.02 & $\mathrm{P}_{2} \mathrm{O}_{5}$ & 0.23 & 0.23 & 0.23 \\
\hline $\mathrm{B}_{2} \mathrm{O}_{3}$ & 0.32 & 3.2 & 1.76 & $\mathrm{PbO}$ & 0.58 & 0.92 & 0.75 \\
\hline $\mathrm{BaO}$ & 0.58 & 1.2 & 0.89 & $\mathrm{PuO}_{2}$ & 1.8 & 3.8 & 2.8 \\
\hline $\mathrm{CaO}$ & 1.1 & 7.0 & 4.05 & $\mathrm{SnO}$ & 0.0 & 0.25 & 0.13 \\
\hline $\mathrm{Cr}_{2} \mathrm{O}_{3}$ & 0.44 & 0.88 & 0.66 & $\mathrm{Ta}_{2} \mathrm{O}_{5}$ & 0.0 & 0.73 & 0.37 \\
\hline $\mathrm{CuO}$ & 0.63 & 1.3 & 0.97 & $\mathrm{TiO}_{2}$ & 1.0 & 1.7 & 1.35 \\
\hline $\mathrm{Fe}_{2} \mathrm{O}_{3}$ & 1.1 & 10.3 & 5.7 & $\mathrm{C}$ & 7.5 & 36.0 & 21.75 \\
\hline $\mathrm{K}_{2} \mathrm{O}$ & 0.24 & 1.2 & 0.72 & $\mathrm{SiO}_{2}$ & 14.17 & 74.10 & 48.49 \\
\hline $\mathrm{MgO}$ & 0.83 & 8.3 & 4.57 & $\mathrm{~F}-$ & 0.04 & 1.8 & 0.6 \\
\hline $\mathrm{MnO}_{2}$ & 0.03 & 0.08 & 0.06 & $\mathrm{Cl}$ & 0.8 & 6.4 & 2.7 \\
\hline $\mathrm{Na}_{2} \mathrm{O}$ & 0.0 & 2.4 & 1.2 & & & & \\
\hline
\end{tabular}

Extensive analyses of the chemical and physical forms of the ashes were conducted by Behrens et al. [5]. The analyzed ash paricles were typically $10 \mathrm{~nm}$ to $\sim 1 \mu \mathrm{m}$ in diameter. Plutonium was found in the oxide form, larger glassy silicate and alumino-silicate phases. Other phases identified in the ash samples include $\mathrm{SiTiO}_{\mathrm{x}}, \mathrm{CaAlSiO}_{\mathrm{x}}, \mathrm{SiO}_{2}$, and $\mathrm{CaMgSiO}_{\mathrm{x}}$.

\subsection{Sand, Slag, and Crucible Description}

$\mathrm{SS} \& \mathrm{C}$ was generated by the bomb reduction process for $\mathrm{PuF}_{4}$ according to a procedure such as:

$$
\begin{aligned}
& \text { powder }\left(2000 \mathrm{~g} \mathrm{~Pa}+2319 \mathrm{~g} \mathrm{PuF}_{4}+272 \mathrm{~g} \mathrm{PuO}_{2}\right)+\text { reductant }(933 \mathrm{~g} \mathrm{Ca})+ \\
& \text { initiator }\left(47 \mathrm{~g} \mathrm{Mg}, \mathrm{KI} \text {, or } \mathrm{Na}_{2} \mathrm{O}_{2}\right)+\mathrm{MgO}(600 \mathrm{~g} \text { sand }+880 \mathrm{~g} \text { crucible) }
\end{aligned}
$$

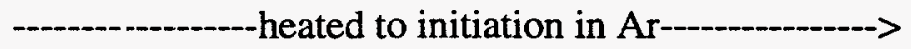

$$
\begin{aligned}
& \text { dirty button }(\mathrm{Pu})+\mathrm{SS} \& \mathrm{C}(20 \mathrm{~g} \mathrm{Pu}+255 \mathrm{~g} \mathrm{Ca}+1480 \mathrm{~g} \mathrm{MgO}+ \\
& \left.1149 \mathrm{~g} \mathrm{CaF}_{2}+54 \mathrm{~g} \mathrm{CaI}_{2}+113 \mathrm{~g} \mathrm{CaO}+\text { trace } \mathrm{K} \text { or } \mathrm{Na}\right)
\end{aligned}
$$

The chemical form of the SSi\&C residue is thought to include $\mathrm{Pu}$ metal, $\mathrm{Ca}$ metal, $\mathrm{CaO}, \mathrm{CaF}_{2}$, $\mathrm{CaI}_{2}, \mathrm{PuO}_{2}$ and $\mathrm{MgO}$. The $\mathrm{MgO}$ is in the form of broken crucible parts and sand; the remaining materials are found mostly in the slag. Pu has penetrated into the surface of the crucibles and is in the slag as both oxide and metal. The nominal SS\&C residue composition, based on an initial review of available literature, is given in Table II.

b Personal conversations with Don Thorp, Safe Sites of Colorado, RFETS. 
Table II. Nominal composition for sand, slag, and crucible

\begin{tabular}{||l|c|}
\hline Compound & wt\% \\
\hline $\mathrm{CaF}_{2}$ & 60 \\
\hline $\mathrm{Ca}$ & 10 \\
\hline $\mathrm{MgO}$ Crucible (-1/8" mesh) & 23 \\
\hline $\mathrm{MgO}$ Sand & 2 \\
\hline $\mathrm{Pu}$ or $\mathrm{PuO}_{2}$ & 5 \\
\hline
\end{tabular}

\subsection{Technology Description}

While the dictionary definition of vitrify states it is "...to change into glass or a glasslike substance by fusion due to heat..." [6], it actually can be used to describe several dissimilar processes when it is applied to waste materials. For the purposes of this study, three types of vitrification are defined:

Complete dissolution: to fully dissolve waste material and form a single glass phase; homogeneous on a molecular scale; generally requires temperatures above $800^{\circ} \mathrm{C}$

Encapsulation: to completely surround waste materials with a glass forming strong chemical bonding between the glass and waste phases; homogeneous on a scale of up to ten times the particle size of the waste material; very low porosity; generally requires temperatures below $800^{\circ} \mathrm{C}$

Agglomeration: to surround waste materials with glass; containing porosity; homogeneous on a scale of roughly 1 to 100 times that of the original waste material; second stage of sintering; can be quickly achieved at low temperature

This study considers the agglomeration and encapsulation of ash and SS\&C materials. Only a fine line distinguishes these two vitrification types. For the purposes of glass frit development, a more graded scale of percent porosity (open and closed) was used to distinguish between final waste forms rather than the vague distinction between encapsulation and agglomeration.

A frit used for encapsulation must sinter at temperatures below $800^{\circ} \mathrm{C}$ (preferably below $700^{\circ} \mathrm{C}$ ) to be useful in the RFETS process. The densification and removal of porosity during sintering of the frit/ash combinations can be monitored via dimensional changes of the mixture, e.g., $\Delta \mathrm{L} / \mathrm{L}_{0}$, where $\mathrm{L}$ is the length of one dimension. For initial-stage sintering by a viscous flow mechanism,

$$
-\frac{\Delta \mathrm{L}}{\mathrm{L}_{0}}=\frac{3 \alpha \mathrm{t}}{8 \mathrm{a} \eta}
$$

where $\alpha$ is the surface tension of glass, $t$ is the heat treatment time, $a$ is the glass particle size, and $\eta$ the viscosity of the material [7]. As the porosity decreases and pores become isolated during the intermediate and final stages of sintering, the kinetics become more complex. For a given sintering temperature, frit/ash densification rate can most easily be increased by decreasing the frit viscosity 
and/or the particle size. In general, closure of open, continuous porosity (i.e., encapsulation) occurs at $\approx 90 \%$ theoretical density. Assuming an initial in-can density of $\approx 30 \%$ (a reasonable tap density), $\Delta \mathrm{L} / \mathrm{L}_{0}$ would have to obtain a value of $\approx 0.3$ to reach a final density of $90 \%$. For silicate glasses, $\alpha$ is roughly $0.3 \mathrm{~N} / \mathrm{n}$. For a first approximation, using Equation (1) and assuming that $\mathrm{t}=7 \times 10^{3} \mathrm{~s}(2 \mathrm{~h})$ with a target $\Delta \mathrm{L} / \mathrm{L}_{0}$ of 0.3 , the sintering viscosity would have to be $10^{6} \mathrm{~Pa} \cdot \mathrm{s}$ for $\mathrm{a}=700 \mu \mathrm{m}$, and $10^{7} \mathrm{~Pa} \cdot \mathrm{s}$ fo: $\mathrm{a}=70 \mu \mathrm{m}$.

For selecting a frit for ash vitrification, two additional factors must be considered. First, reactions of glass with waste may alte' the effective $\alpha$, a, and $\eta$, thus influence sintering. Second, gas generation may blow glass into a foam when the porosity is closed. Gas can be generated by decomposition of organic compounds, atmospheric oxidation of carbon, or redox reactions within the waste. For successful encapsulation, the temperature at which foaming begins $\left(T_{F}\right)$ must be higher than the temperature at which the waste is encapsulated by sintering $\left(T_{S}\right)$. Hence, $T_{S}<T_{U}$ $<\mathrm{T}_{\mathrm{F}}$, where $\mathrm{T}_{\mathrm{U}}$ is the upper processing temperature $\left(\mathrm{T}_{\mathrm{U}} \leq 800^{\circ} \mathrm{C}\right)$, and the temperature interval, $\Delta \mathrm{T}=\mathrm{T}_{\mathrm{U}}-\mathrm{T}_{\mathrm{S}}$ is large enough to accommodate the temperature gradients produced during in-can processing as well as variaticins in the waste.

\subsection{Glass Families}

Initial searches of glass databases and literature have identified six glass families with the appropriate viscosity-temperature relationship for application in ash and SS\&C vitrification: antimony vanadium phosphate (AVP), iron vanadium phosphate (IVP), tin zinc phosphate (TZP), soda-lime silicate (SLS), alkcli borosilicate (ABS), and alkali borate (AB). Data from literature and glass property databases weris used to calculate initial glass compositions and composition variations for the scoping studies described in this report. Each of these glass families have unique set of properties and characteristics that make them useful for ash material vitrification.

\section{Antimony Vanadium Phosphate}

The selection of AVP systems was based on the fact that these glasses generally can be fabricated at low temperatures (below $\left.1000^{\circ} \mathrm{C}\right)$ and the glass transition temperatures $\left(\mathrm{T}_{\mathrm{g}}\right)$ are low $\left(<400^{\circ} \mathrm{C}\right)$ relative to silicate or borosilizate glasses. The use of frit with low $T_{g}$, and hence low $T_{S}$, can increase $\Delta T\left(=T_{U}-T_{S}\right)$. Adilitional benefits of using these systems are relatively lower energy costs for frit fabrication and waste form sintering process. The disadvantages of these systems may be related to higher costs of chemicals, availability of frit, toxicity of antimony oxide $\left(\mathrm{Sb}_{2} \mathrm{O}_{3}\right)$ and vanadium oxide $\left(\mathrm{V}_{2} \mathrm{O}_{5}\right)$, and durability in aqueous solutions.

\section{Iron Vanadium Phosphate}

In an earlier study of AVP gasses, $\mathrm{Fe}_{2} \mathrm{O}_{3}$ was shown to be soluble at $11.56 \mathrm{wt} \%$ in the AVPbased glass. Hence, the possibility of replacing $\mathrm{Sb}_{2} \mathrm{O}_{3}$ by $\mathrm{Fe}_{2} \mathrm{O}_{3}$ and at the same time reducing the concentration of $\mathrm{V}_{2} \mathrm{O}_{5}$ was a1tempted to help limit the cost and toxicity of the glass frit while maintaining acceptable properties for ash vitrification.

\section{Tin Zinc Phosphate}

Tin oxide $(\mathrm{SnO})$ and zinc oxide $(\mathrm{ZnO})$ are soluble in phosphate glass. The glass system, $\mathrm{SnO}$ $\mathrm{P}_{2} \mathrm{O}_{5}$, can be melted at temperatures as low as $700^{\circ} \mathrm{C}$. The $\mathrm{T}_{\mathrm{g}}$ can be as low as $200^{\circ} \mathrm{C}$ when a small amount of fluorine is added. Incorporation of $\mathrm{ZnO}$ was shown to have little effect on the 
melting temperature of the AVP glasses. Therefore, it was assumed that $\mathrm{SnO}-\mathrm{ZnO}-\mathrm{P}_{2} \mathrm{O}_{5}$ glasses should have glass melting temperature close to that of $\mathrm{SnO}-\mathrm{P}_{2} \mathrm{O}_{5}$ glass as well as similar $\mathrm{T}_{\mathrm{g}}$. Incorporation of $\mathrm{ZnO}$, however, is expected to improve the acid leach resistance of the glass (in anticipation of an acid leaching Pu-recoverability standard). The use of TZP glasses can reduce materials costs and hazardous waste concerns. However, the TZP glasses that are formulated to have low $\mathrm{T}_{\mathrm{g}} \mathrm{s}$ may be less durable than the AVP glasses.

\section{Soda-lime Silicate}

A common window glass was found to have the appropriate viscosity-temperature relationship for the encapsulation of ash and SS\&C, with a viscosity of $3.7 \times 10^{6} \mathrm{~Pa} \cdot \mathrm{S}$ at $700^{\circ} \mathrm{C}$ and $7.2 \times 10^{4} \mathrm{~Pa} \cdot \mathrm{S}$ at $800^{\circ} \mathrm{C}$ [8]. According to Equation (1), a $200 \mu \mathrm{m}$ soda-lime silicate frit would sinter in roughly $1 \mathrm{~h}$ at $700^{\circ} \mathrm{C}$. Additionally, this glass is manufactured in megaton quantities in the U.S.; hence, it is inexpensive, and its properties have been studied and are well understood. The chemical durability of this window glass is considered to be extremely high [9].

\section{Alkali Borosilicate}

Alkali borosilicate glasses have widely varying properties, depending on composition. These glasses have been studied extensively for commercial and waste applications and the effects of composition and temperature on glass viscosity are available as mathematic functions. Glass formulation can be tailored to match the viscosity-temperature requirements for ash encapsulation, once they are defined. Borosilicate glasses generally have $\mathrm{T}_{\mathrm{g}} \mathrm{s}$ above $400^{\circ} \mathrm{C}$; hence, these glasses are useful for encapsulation at temperatures between $500^{\circ} \mathrm{C}$ and $800^{\circ} \mathrm{C}$. Like SLS glasses, ABS glasses generally exhibit high chemical durability and are mass produced in the U.S.

\section{Alkali Borate}

Alkali borate based glasses were investigated as frit materials for ash encapsulation for a variety of reasons. Alkali borate melts can be processed at significantly lower temperatures than silicate or borosilicate compositions and generally can be prepared from relatively inexpensive and readily available industrial compounds such as Borax. For a given sintering temperature (i.e., $500^{\circ} \mathrm{C}$ or less) $\mathrm{AB}$ frits have relatively lower viscosities than silicate and borosilicate glasses and would thus allow for more extensive sintering. However, the viscosity and activation energy for viscous flow of $\mathrm{AB}$ glasses may still not be low enough to vitrify the ash/frit mixture in the appropriate time scale. Furthermore, $\mathrm{AB}$ and other low melting glasses are generally less durable than silicate and borosilicate glasses in aqueous solutions.

\subsection{Evaluation Method}

The processing temperature range was a critical parameter for evaluating different glass frit families and compositions for application to vitrification of ash materials. For each frit tested, the $T_{S}$ value was evaluated. The frits that were able to vitrify ash and SS\&C at lower temperatures were favored. Volume change (i.e., sintering) of the frit/waste simulant mixture was used as a discriminator for agglomeration. For example, an AVP glass/ash mixture that shrank $20 \%$ when held for $1 \mathrm{~h}$ at $400^{\circ} \mathrm{C}$ was favored over a glass/ash mixture that did not shrink until $500^{\circ} \mathrm{C}$. Other properties, such as recoverability or reactivity, were not systematically evaluated since the testing parameters for those properties were not received until the screening tests were completed. Recoverability and reactivity tests will be performed in future studies. 


\subsection{EXPERIMENTAL APPROACH}

The preliminary scoping tests reported here were designed to identify glass families and compositions that are best suited to the agglomeration/encapsulation of ashes and SS\&C stored at RFETS. For these tests, glasis frits were fabricated, sized, mixed with waste simulants, heat treated, and characterized. This section describes the general methods employed for these steps. Further discussions of specific experimental conditions are given in Section 3.

\subsection{Ash Simulants}

As described in Section 1.1, the composition and chemical form of ashes at RFETS are highly variable. To bracket the possible processing differences seen in the diverse waste stream, several ash simulants were employed in this study (listed in Table III). These ash simulants were generated from the burning or: incineration of wood, solid wastes, and fossil fuels and are diverse in density, particle size distritutions, and off-gas characteristics. However, no formal characterization other than composition analysis was performed on these simulants.

Table III. Ash simulant compositions in wt\% oxides

\begin{tabular}{|c|c|c|c|c|c|c|c|c|}
\hline & $\mathrm{M}$ ash & $\mathrm{J}$ ash & $\begin{array}{c}\text { Pozzolan } \\
\text { ash }\end{array}$ & $\begin{array}{l}\text { BF, Fly } \\
\text { ash }\end{array}$ & $\begin{array}{c}\mathrm{U} \text { of } \mathrm{M} \\
\text { ash }\end{array}$ & $\begin{array}{c}\text { VPP } \\
\text { Fly ash }\end{array}$ & $\begin{array}{c}\text { Tacoma } \\
\text { ash }\end{array}$ & $\begin{array}{c}\text { RFETS } \\
\text { ash }\end{array}$ \\
\hline $\mathrm{Al}_{2} \mathrm{O}_{3}$ & 8.50 & 10.86 & 23.77 & 6.07 & 12.74 & 15.00 & 12.77 & 3.33 \\
\hline $\mathrm{B}_{2} \mathrm{O}_{3}$ & 0.11 & 0.11 & & & 2.39 & & & 1.76 \\
\hline $\mathrm{BaO}$ & 0.14 & 0.12 & & & 0.39 & & 0.07 & 0.89 \\
\hline C & 17.45 & 22.23 & 5.13 & & 9.65 & 3.32 & 0.11 & 21.75 \\
\hline $\mathrm{CaO}$ & 23.79 & 20.57 & 8.92 & 39.18 & 16.29 & 10.72 & 6.88 & 4.05 \\
\hline $\mathrm{Cl}$ & & & & & 1.06 & & & 2.70 \\
\hline $\mathrm{Cr}_{2} \mathrm{O}_{3}$ & 0.10 & 0.94 & & & 0.05 & & & 0.66 \\
\hline $\mathrm{CuO}$ & 0.11 & 0.4 .4 & & & & & & 0.97 \\
\hline $\mathrm{F}$ & & & & & & & & 0.60 \\
\hline $\mathrm{Fe}_{2} \mathrm{O}_{3}$ & 2.36 & 1.57 & 5.05 & 0.28 & 1.87 & 5.92 & 3.07 & 5.70 \\
\hline $\mathrm{K}_{2} \mathrm{O}$ & 7.35 & $8.4 \overline{3}$ & 0.58 & 0.40 & 1.83 & & 1.87 & 0.72 \\
\hline $\mathrm{MgO}$ & 3.48 & 4.97 & 2.99 & 20.69 & 2.17 & 2.44 & 1.01 & 4.57 \\
\hline $\mathrm{MnO}$ & 0.18 & 0.59 & 0.04 & 0.51 & 0.05 & & 0.12 & 0.06 \\
\hline $\mathrm{Na}_{2} \mathrm{O}$ & 2.16 & 2.112 & 3.52 & 0.28 & 2.83 & & 3.70 & 1.20 \\
\hline $\mathrm{NiO}$ & 1.40 & 1.40 & & & & & & 0.45 \\
\hline $\mathrm{P}_{2} \mathrm{O}_{5}$ & 2.98 & 1.92 & 0.60 & & 11.01 & & 0.57 & 0.23 \\
\hline $\mathrm{PbO}$ & & & & & 0.48 & & & 0.75 \\
\hline $\mathrm{SiO}_{2}$ & 26.10 & 17.97 & 48.53 & 42.70 & 29.48 & 59.97 & 65.01 & 48.49 \\
\hline $\mathrm{SnO}$ & & & & & 0.40 & & & 0.13 \\
\hline $\mathrm{SO}_{3}$ & 1.88 & 3.10 & 0.58 & 2.54 & 1.92 & 0.97 & & \\
\hline $\mathrm{SrO}$ & & & 0.17 & 0.04 & & & 0.04 & \\
\hline $\mathrm{Ta}_{2} \mathrm{O}_{5}$ & & & & & & & & 0.37 \\
\hline $\mathrm{TiO}_{2}$ & 1.60 & 2.67 & & & 3.75 & & 0.64 & 1.35 \\
\hline $\mathrm{ZnO}$ & 0.31 & 0.19 & & & 1.63 & & & \\
\hline $\mathrm{ZrO}_{2}$ & & & 0.14 & 0.05 & & & & \\
\hline
\end{tabular}




\subsection{Sand, Slag, and Crucible Simulants}

The simulant used for SS\&C is composed of crushed MgO crucibles ( $1 / 8$ inch dimension), coarse $\mathrm{MgO}$ sand, $\mathrm{CaF}_{2}$, shredded $\mathrm{Ca}$, and $\mathrm{Hf} / \mathrm{HfO}_{2}$ as $\mathrm{Pu} / \mathrm{PuO}_{2}$ surrogates. These components were mixed in the proportions listed in Table II. The complete mixture was sized to pass through an $1 / 8$-inch sieve.

\subsection{Preparation of Glass Frits}

Glasses were batched from oxides, carbonates, phosphates, boric acid, Borax $5 \mathrm{Mol}$, sodium fluoride, and tin fluoride and melted according to previously reported procedures [10]. The melting temperatures of the glass frits were $1450^{\circ} \mathrm{C}$ for SLS, $1200^{\circ} \mathrm{C}$ for $\mathrm{ABS}, 1000^{\circ} \mathrm{C}$ to $1100^{\circ} \mathrm{C}$ for $\mathrm{AVP}, 750^{\circ} \mathrm{C}$ for TZP, and $1000^{\circ} \mathrm{C}$ for $\mathrm{AB}$. After melting, these glasses were quenched by casting on a steel plate, crushed in a tungsten carbide disc mill, and sized with dry sieves.

\subsection{Crucible Tests}

Glass frits were mixed with ash or SS\&C simulants and loaded into alumina crucibles in roughly $10-\mathrm{g}$ batches. These loaded crucibles were then heat-treated in calibrated furnaces under air atmosphere at preset temperatures for times discussed in Section 3. Upon removal from the furnace, the samples were allowed to cool to room temperature in ambient air. Photographs and photomicrographs were taken of many samples.

\subsection{Gradient Furnace Tests}

Glass frits were mixed with ash or SS\&C simulants and loaded into alumina boats roughly 10 inches long. These boats were quickly placed into a preheated furnace with a linear temperature gradient. The gradient of roughly $1^{\circ} \mathrm{C} / \mathrm{mm}$ was held in this furnace by five temperature control zones. Each sample was isothermally exposed to a range of temperatures, and in some cases thin sections were prepared according previously reported procedures [10]. These tests allowed the evaluation of processing temperature ranges for particular frit and waste combinations.

\subsection{Thermogravimetric Analysis}

The weight loss of several ash simulant and ash simulant/frit mixtures was measured. These measurements were performed in roughly $10-\mathrm{g}$ batches in a unique apparatus designed at PNNL. A ramp rate of $5^{\circ} \mathrm{C} / \mathrm{min}$ was maintained during weight loss measurements.

\subsection{RESULTS AND OBSERVATIONS}

Each of the six glass systems was tested independently using variations of the same general experimental approach described above. However, some aspects of the vitrification process are expected to be similar for all glasses, including the temperature-time-location relationships within the Vollrath canister and the weight loss characterization of ash simulants. Results from thermal profiling and weight loss studies are given in Sections 3.1 and 3.2, respectively. Results and observations from frit testing are described in Sections 3.3 to 3.8 .

\subsection{Thermal Profiling of Vollrath Can}

Canister heating exposes the batch to a range of temperatures with a higher temperature at the 
surface and a lower temperature in the center. It is important that the maximum temperature within the material $\left(\mathrm{T}_{\mathrm{U}}\right)$ does not exceed the foaming temperature $\left(\mathrm{T}_{\mathrm{F}}\right)$, and that the lowest local temperature anywhere in the sody of the waste form is higher than the sintering temperature $\left(T_{S}\right)$.

A thermal profile was measured in a full-scale Vollrath can with frit and $20 \mathrm{wt} \%$ ash. This test was performed at $650^{\circ} \mathrm{C}$ for $6 \mathrm{~h}$. 'The results of this study were previously reported and are attached as Appendix 7.2. According to measurements reported in Appendix 7.2, the maximum temperature difference within an $\mathrm{ABS}$ frit in a Vollrath container is about $50^{\circ} \mathrm{C}$ after $6 \mathrm{~h}$ heating. Hence, if $\Delta \mathrm{T}$ $=\mathrm{T}_{U}-\mathrm{T}_{S} \geq 100^{\circ} \mathrm{C}$, it is likely' that the waste can be encapsulated without foaming. However, the temperature difference within the Vollrath can is dependent upon furnace temperature and time. Further studies will more completely characterize the thermal history of the glass frit and waste mixture before final frit optimization to ensure that an appropriate $\Delta \mathrm{T}$ is maintained.

\subsection{Thermogravimetric Analysis of Ash Simulants}

Foam or volume expansion cian be realized if off-gassing occurs in the waste/frit mixture while a viscous fluid phase is present. Foaming was observed in preliminary testing when frit formed a viscous glass while carbon in the ash was being oxidized [5]. Figure 1 shows examples of batch foaming.

Thermogravimetric analysis was used to evaluate the temperature range for off-gas of our ash simulants. Figure 2 shows the off-gas rate as a function of temperature for 2(a) Pozzolan ash with $20 \mathrm{wt} \%$ activated carbon in a 20:80 mix with SLS frit, and 2(b) the U of M ash. Figure 3 shows the weight as a function of temperature for $\mathrm{J}$ ash. The different ash simulants tested have different off-gas characteristics, as is evident in Figures 2 and 3. Generally, off-gas from organics and water occurs at temperatures below $200^{\circ} \mathrm{C}$ and from carbon and carbonates occurs between roughly $380^{\circ} \mathrm{C}$ and $600^{\circ} \mathrm{C}$. The formation of viscous melts in these temperature regions should be avoided for vitrification of ashes.

\subsection{Antimony Vanadium Phosphate Frit}

The AVP frits, shown in Tabe IV, were fabricated at temperatures between $1000^{\circ} \mathrm{C}$ and $1100^{\circ} \mathrm{C}$. Based on the crystallization tendency as visually determined from the quenched glass samples, $\mathrm{BaO}, \mathrm{CaO}, \mathrm{Fe}_{2} \mathrm{O}_{3}, \mathrm{TiO}_{2}$, and $\mathrm{ZnO}$ were soluble in the AVP-based glass at $11.56 \mathrm{wt} \%$. $\mathrm{CeO}_{2}$ and $\mathrm{SiO}_{2}$ were not soluble at 5.83 and $11.56 \mathrm{wt} \%$ concentrations in the glass, respectively; $\mathrm{SnO}_{2}$ was soluble at $5.83 \mathrm{wt} \%$ and not :soluble at $11.56 \mathrm{wt} \%$. Hence, the AVP glasses, AVP-100, AVP-104, AVP-105, AVP-109, and AVP-116, were selected for ash-sintering tests (AVP-111 glass with $11.56 \mathrm{wt} \% \mathrm{Fe}_{2} \mathrm{O}_{3}$ was not tested; rather the IVP glasses with higher $\mathrm{Fe}_{2} \mathrm{O}_{3}$ and lower $\mathrm{V}_{2} \mathrm{O}_{5}$ were evaluated for the ash-sintering capability). For the evaluation of the AVP frit, $20 \mathrm{wt} \%$ Pozzolan ash was used.

Figure 4 shows the results of a series of tests with $20 \mathrm{wt} \%$ Pozzolan ash and varied AVP frit compositions. Figure 4(a) shows the frit and ash mixtures before heat treatment. After $1 \mathrm{~h} \mathrm{at}$ $400^{\circ} \mathrm{C}$, no ash sintering was $\epsilon$ vident for all samples as demonstrated in Figure 4(b). The furnace temperature was raised to 430$)^{\circ} \mathrm{C}$ for $1 \mathrm{~h}$. The mixture of AVP-105 frit with $20 \mathrm{wt} \%$ Pozzolan ash sintered after $1 \mathrm{~h}$ at $430^{\circ} \mathrm{C}$, the rest of samples showed no indication of sintering; see Figure 4(c). The furnace temperature was then increased to $450^{\circ} \mathrm{C}$, at which AVP-100 and AVP-116 with ash showed significant volume reduction after $1 \mathrm{~h}$, as illustrated in Figure 1(d). At the same temperature, the AVP-105 with ash became more dense, as suggested by the formation of a glassy phase. No significant progress in sintering was observed for AVP-104 and AVP-109 with ash at 


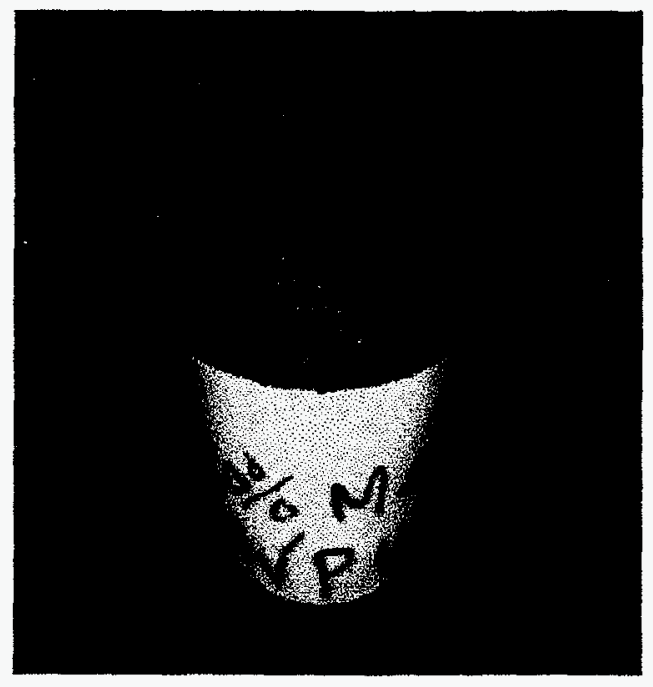

Figure 1. Foaming of an ash simulant and frit mixture at $500^{\circ} \mathrm{C}$

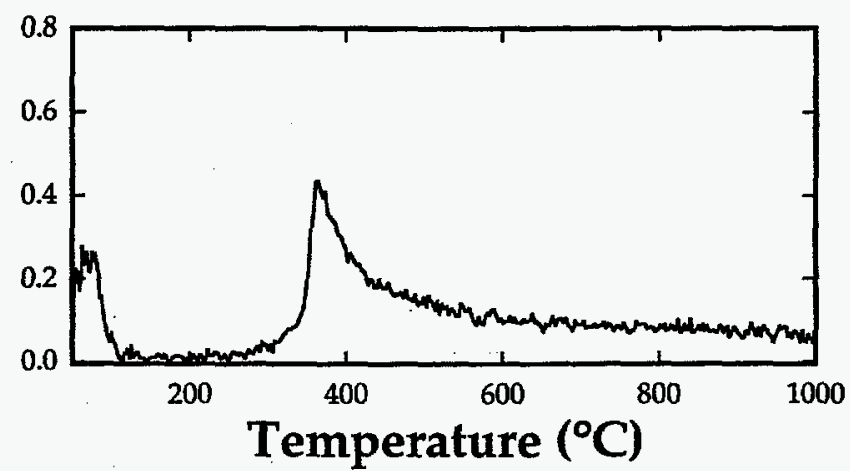

(a)

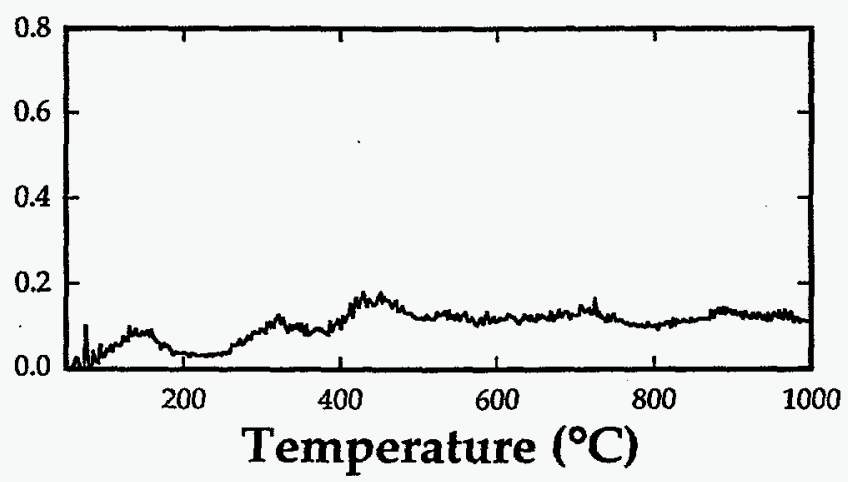

(b)

Figure 2. Off gas rate for: (a) $80 \mathrm{wt} \%$ SLS frit and Pozzolan ash with 20 wt\% activated carbon, and (b) the U of $M$ ash 


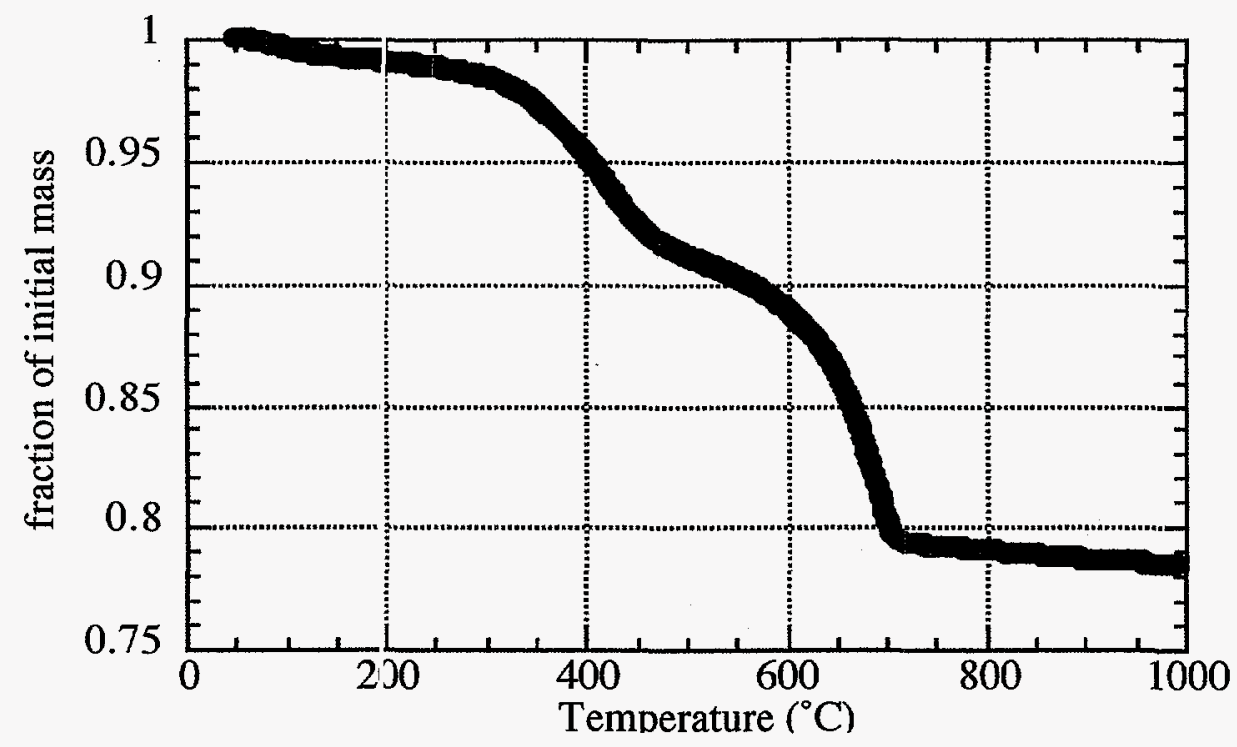

Figuse 3. Thermogravimetric analysis of $J$ ash

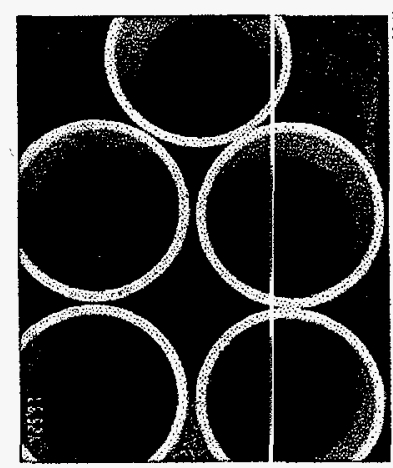

(a)

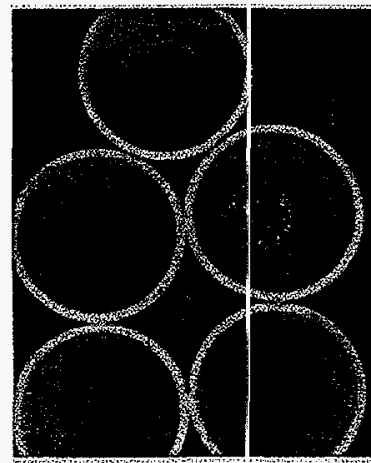

(d)

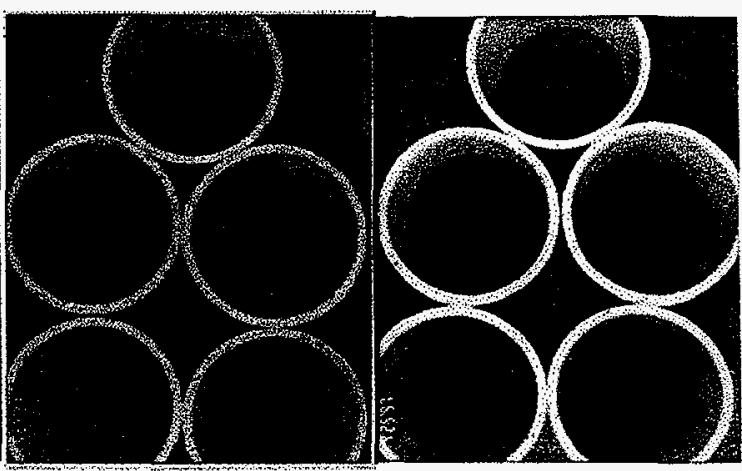

(c)

(b)

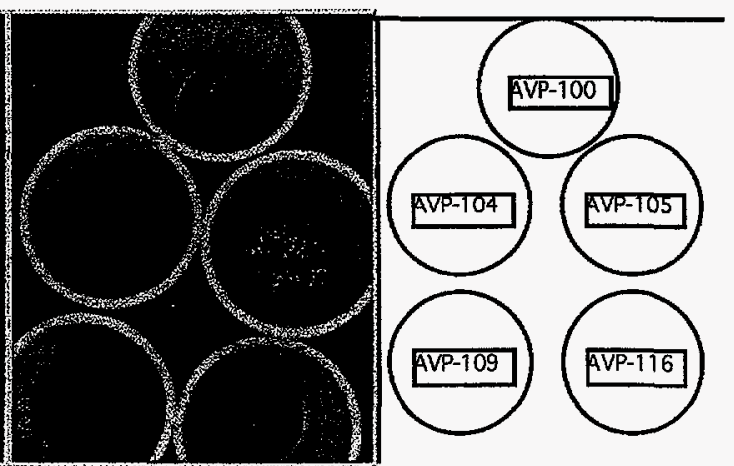

(e)

Figure 4. AVP frit evaluaticn for ash sintering capability: (a) the mixtures of AVP frit with 20 wt\% Pozzolan ash prior to heat treatment, (b) $400^{\circ} \mathrm{C}-1 \mathrm{~h}$, (c) $430^{\circ} \mathrm{C}-1 \mathrm{~h}$, (d) $450^{\circ} \mathrm{C}-1 \mathrm{~h}$, and (e) $500^{\circ} \mathrm{C}-1 \mathrm{~h}$ (the AVP frits are marked on the drawing at the right corner) 
$450^{\circ} \mathrm{C}$. Finally, with the furnace temperature increased to $500^{\circ} \mathrm{C}$, more densification of AVP-100 and AVP-116 with ash were observed after $1 \mathrm{~h}$, as shown in Figure 4(e). Sintering of AVP-104 with ash was also found at $500^{\circ} \mathrm{C}$. However, no significant progress was evident on sintering the AVP-109 with ash at $500^{\circ} \mathrm{C}$. In summary, the $\mathrm{T}_{S}$ can be ranked as AVP-105 $<\mathrm{AVP}-100<\mathrm{AVP}$ $116<$ AVP-104 < AVP-109.

Table IV. Antimony vanadium phosphate frit compositions in wt\%

\begin{tabular}{|c|c|c|c|c|c|c|c|c|c|}
\hline Oxide & $\begin{array}{l}\text { AVP- } \\
100\end{array}$ & $\begin{array}{l}\text { AVP- } \\
101\end{array}$ & $\begin{array}{l}\text { AVP- } \\
102\end{array}$ & $\begin{array}{l}\text { AVP- } \\
104\end{array}$ & $\begin{array}{l}\text { AVP- } \\
116\end{array}$ & $\begin{array}{c}\text { AVP- } \\
117\end{array}$ & $\begin{array}{c}\text { AVP- } \\
112\end{array}$ & $\begin{array}{l}\text { AVP- } \\
113\end{array}$ & $\begin{array}{l}\text { AVP } \\
110\end{array}$ \\
\hline $\mathrm{BaO}$ & 0.00 & 0.00 & 5.83 & 11.56 & 0.00 & 0.00 & 0.00 & 0.00 & 0.00 \\
\hline $\mathrm{CaO}$ & 0.00 & 0.00 & 0.00 & 0.00 & 5.83 & 11.56 & 0.00 & 0.00 & 0.00 \\
\hline $\mathrm{CeO}_{2}$ & 0.00 & 0.00 & 0.00 & 0.00 & 0.00 & 0.00 & 5.83 & 11.56 & 0.00 \\
\hline $\mathrm{Fe}_{2} \mathrm{O}_{3}$ & 0.00 & 0.00 & 0.00 & 0.00 & 0.00 & 0.00 & 0.00 & 0.00 & 5.83 \\
\hline $\mathrm{P}_{2} \mathrm{O}_{5}$ & 20.00 & 23.53 & 22.16 & 20.81 & 22.16 & 20.81 & 22.16 & 20.81 & 22.16 \\
\hline $\mathrm{PbO}$ & 15.00 & 0.00 & 0.00 & 0.00 & 0.00 & 0.00 & 0.00 & 0.00 & 0.00 \\
\hline $\mathrm{Sb}_{2} \mathrm{O}_{3}$ & 25.00 & 29.41 & 27.70 & 26.01 & 27.70 & 26.01 & 27.70 & 26.01 & 27.70 \\
\hline $\mathrm{SiO}_{2}$ & 0.00 & 0.00 & 0.00 & 0.00 & 0.00 & 0.00 & 0.00 & 0.00 & 0.00 \\
\hline $\mathrm{SnO}_{2}$ & 0.00 & 0.00 & 0.00 & 0.00 & 0.00 & 0.00 & 0.00 & 0.00 & 0.00 \\
\hline $\mathrm{TiO}_{2}$ & 0.00 & 0.00 & 0.00 & 0.00 & 0.00 & 0.00 & 0.00 & 0.00 & 0.00 \\
\hline $\mathrm{V}_{2} \mathrm{O}_{5}$ & 40.00 & 47.06 & 44.31 & 41.62 & 44.31 & 41.62 & 44.31 & 41.62 & 44.31 \\
\hline \multirow[t]{2}{*}{$\mathrm{ZnO}$} & 0.00 & 0.00 & 0.00 & 0.00 & 0.00 & 0.00 & 0.00 & 0.00 & 0.00 \\
\hline & $\begin{array}{l}\text { AVP- } \\
111\end{array}$ & $\begin{array}{c}\text { AVP- } \\
114\end{array}$ & $\begin{array}{l}\text { AVP- } \\
115\end{array}$ & $\begin{array}{l}\text { AVP- } \\
106\end{array}$ & $\begin{array}{l}\text { AVP- } \\
108\end{array}$ & $\begin{array}{l}\text { AVP- } \\
107\end{array}$ & $\begin{array}{l}\text { AVP- } \\
109\end{array}$ & $\begin{array}{l}\text { AVP- } \\
103\end{array}$ & $\begin{array}{c}\text { AVP- } \\
105\end{array}$ \\
\hline $\mathrm{BaO}$ & 0.00 & 0.00 & 0.00 & 0.00 & 0.00 & 0.00 & 0.00 & 0.00 & 0.00 \\
\hline $\mathrm{CaO}$ & 0.00 & 0.00 & 0.00 & 0.00 & 0.00 & 0.00 & 0.00 & 0.00 & 0.00 \\
\hline $\mathrm{CeO}_{2}$ & 0.00 & 0.00 & 0.00 & 0.00 & 0.00 & 0.00 & 0.00 & 0.00 & 0.00 \\
\hline $\mathrm{Fe}_{2} \mathrm{O}_{3}$ & 11.56 & 0.00 & 0.00 & 0.00 & 0.00 & 0.00 & 0.00 & 0.00 & 0.00 \\
\hline $\mathrm{P}_{2} \mathrm{O}_{5}$ & 20.81 & 22.16 & 20.81 & 22.16 & 20.81 & 22.16 & 20.81 & 22.16 & 20.81 \\
\hline $\mathrm{PbO}$ & 0.00 & 0.00 & 0.00 & 0.00 & 0.00 & 0.00 & 0.00 & 0.00 & 0.00 \\
\hline $\mathrm{Sb}_{2} \mathrm{O}_{3}$ & 26.01 & 27.70 & 26.01 & 27.70 & 26.01 & 27.70 & 26.01 & 27.70 & 26.01 \\
\hline $\mathrm{SiO}_{2}$ & 0.00 & 5.83 & 11.56 & 0.00 & 0.00 & 0.00 & 0.00 & 0.00 & 0.00 \\
\hline $\mathrm{SnO}_{2}$ & 0.00 & 0.00 & 0.00 & 5.83 & 11.56 & 0.00 & 0.00 & 0.00 & 0.00 \\
\hline $\mathrm{TiO}_{2}$ & 0.00 & 0.00 & 0.00 & 0.00 & 0.00 & 5.83 & 11.56 & 0.00 & 0.00 \\
\hline $\mathrm{V}_{2} \mathrm{O}_{5}$ & 41.62 & 44.31 & 41.62 & 44.31 & 41.62 & 44.31 & 41.62 & 44.31 & 41.62 \\
\hline $\mathrm{ZnO}$ & 0.00 & 0.00 & 0.00 & 0.00 & 0.00 & 0.00 & 0.00 & 5.83 & 11.56 \\
\hline
\end{tabular}

The AVP-105 frit was further tested with $20 \mathrm{wt} \%$ Pozzolan ash loading in a temperature gradient furnace for $16 \mathrm{~h}$. The temperature gradient was set for $1.28^{\circ} \mathrm{C} / \mathrm{mm}$ for a furnace span of $330 \mathrm{~mm}$ (or 13 inches long), which covered the temperature region between $338^{\circ} \mathrm{C}$ and $762^{\circ} \mathrm{C}$. Figure 5 shows photographs of the ash-sintering results in the temperature region between $400^{\circ} \mathrm{C}$ and $745^{\circ} \mathrm{C}$. The results showed that the ash-sintering temperature was greater than $390^{\circ} \mathrm{C}$. This is 
slightly lower than the sinteriag temperature found from isothermal heat treatment. The difference in the sintering temperature cian be attributed to the heat-treatment time difference.

At temperatures between $390^{\circ} \mathrm{C}$ and $530^{\circ} \mathrm{C}$, the sintered form appeared to be partially glassy, whereas above $530^{\circ} \mathrm{C}$, it appeared to be crystalline. The optimum processing temperature not only is based on the ash sintering but also considers the densification of the sintered form. Figure 6 shows cross sections of sintered samples at three temperatures; the samples were prepared from the gradient temperature treated AVP-105 with $20 \mathrm{wt} \%$ Pozzolan ash. At $\sim 400^{\circ} \mathrm{C}$, the sintered form had a few pores, as revealed in Figure $6(\mathrm{a})$. At $\sim 595^{\circ} \mathrm{C}$, the pore density was significantly higher as compared to that of low temperature sintered sample, as shown in Figure 6(b). Figure 6(c) shows the pore density was even greater and the sizes of the pores were generally larger at $\sim 640^{\circ} \mathrm{C}$ than those of the lower temperature sintered samples. Therefore, by considering sample densification, the optimum $\mathrm{T}_{\text {s }}$ region for AVP-105 with $20 \mathrm{wt} \%$ Pozzolan ash was between $400^{\circ} \mathrm{C}$ and $430^{\circ} \mathrm{C}$.

In the development of the AVP frit for ash sintering, it was found that ash type had significant impact on $T_{S}$. Figure 7 shows the AVP-100 frit mixed with $20 \mathrm{wt} \%$ of three different ashes: J ash, $\mathrm{M}$ ash, and Pozzolan ash. Figgure 7(a) shows the three samples before the heat treatment. After 25 min at $450^{\circ} \mathrm{C}$, the results shown in Figure $7(\mathrm{~b})$ demonstrated Pozzolan ash being sintered with the frit, gas evolution (presumably $\mathrm{CO}_{2}$ ) from the sample with $\mathrm{J}$ ash, and no detectable reaction for the sample with $\mathrm{M}$ ash. After the heat treatment for $1 \mathrm{~h}$, no significant progress was detectable for the samples with $J$ ash and $M$ ash., whereas the sample with Pozzolan ash was sintered completely [see Figure 7(c)]. After $2 \mathrm{~h}$ at $45\left(1^{\circ} \mathrm{C}\right.$ there were no visible changes in the samples heated for $1 \mathrm{~h}$, as seen in Figure 7(d). The Pozzolan ash sample was then removed from testing. The samples with $\mathrm{J}$ ash and $\mathrm{M}$ ash were further heat-treated at $500^{\circ} \mathrm{C}$ for $25 \mathrm{~min}$. Figure 7(e) shows no visible progress in the $J$ ash sample and severe foaming in the $M$ ash sample (the sample with Pozzolan ash treated at lower temperature was included for comparison).

Two major factors were cons dered as explanations for the observed effects of ash on sintering behavior. First, diverse compositions exist among the ashes investigated, as shown in Table III. It is possible that the AVP fril reacted with some of the ash constituents at low temperatures, altering the frit deformation temperature or $\mathrm{T}_{\mathrm{g}}$ and possibly the sintering mechanism. Depending on the type and the extent of chemical reactions, the ash sintering temperature might be increased or decreased accordingly. Another factor is that these ashes have vastly different densities. The ash density seemed to be in the o:der, Pozzolan ash $>\mathrm{M}$ ash $>\mathrm{J}$ ash. With the same ash loading of 20 $w t \%$, it is expected that the volume loading of Pozzolan ash will be less for $J$ ash and $M$ ash, since the particle sizes of all three ashes were about the same after they were ground with frit. Hence, the volume ratio of frit to ash should have increased in the same order. Therefore, it is possible that for the $20 \mathrm{wt} \%$ ash loading, the volume of the AVP-100 frit was not sufficient to sinter or bind the given amount of either $\mathrm{J}$ ash or $\mathrm{M}$ ash because the frit underwent significantly higher dilution.

The comparison of the heat-treatment results between the samples with $\mathrm{J}$ ash and $\mathrm{M}$ ash (Figure 7) also suggested that the two ashes contained different chemical sources or forms of carbons. Both ashes contained significant arnounts of these carbon sources. The extent of the reactions of residual carbon forms in the $\mathrm{M}$ ash with oxygen was significant at $500^{\circ} \mathrm{C}$ and was much less at temperatures below $500^{\circ} \mathrm{C}$. On the other hand, the reactions of the carbon forms in the $\mathrm{J}$ ash was significant at temperatures as low as $450^{\circ} \mathrm{C}$ but may not have continued significantly at higher temperatures since no volume: expansion was detectable at $500^{\circ} \mathrm{C}$. Pozzolan ash has much less residual carbon, as shown by the chemical analysis given in Table III. No detectable weight loss was found at $450^{\circ} \mathrm{C}$, according to the measurements of the sample's initial and final weight. 


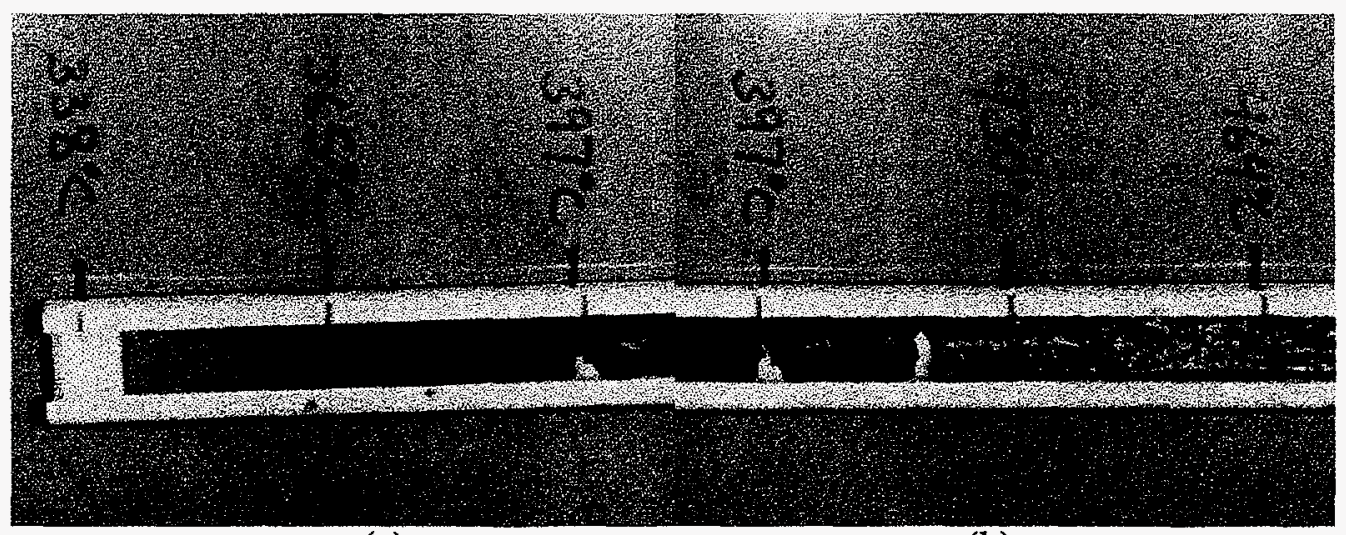

(a)

(b)

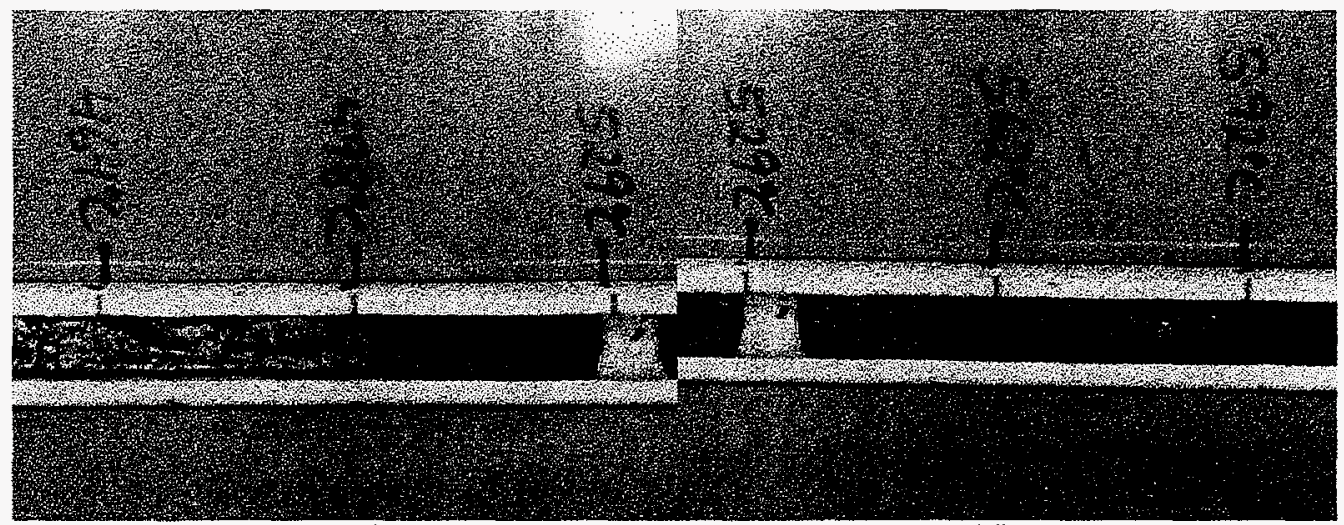

(c)

(d)

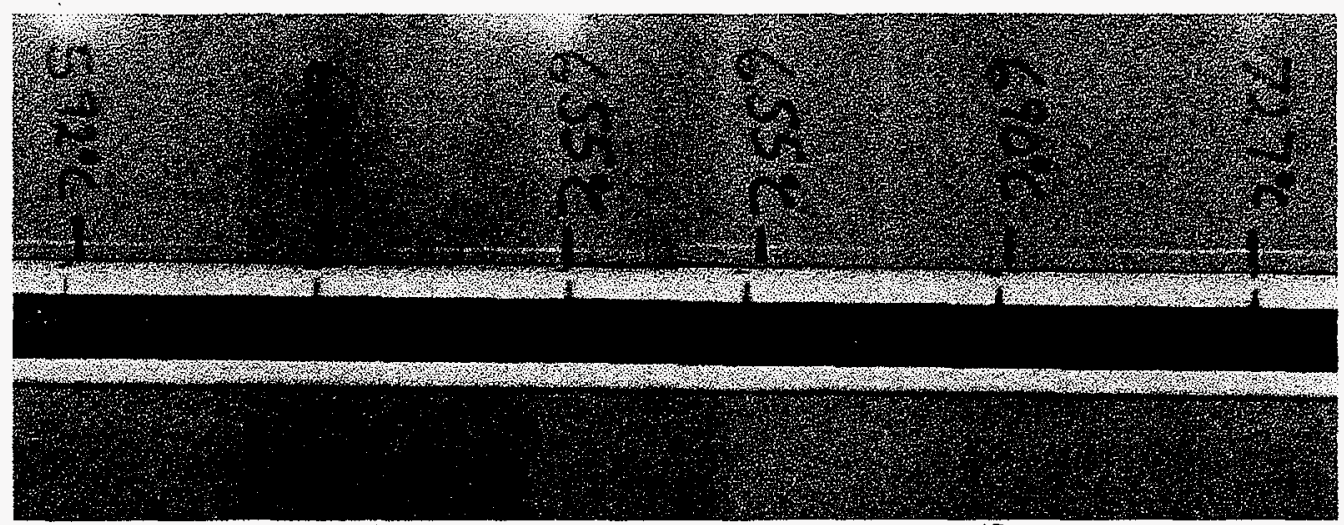

(e)

(f)

Figure 5. Heat-treatment of $80 \mathrm{wt} \%$ AVP-105 - $20 \mathrm{wt} \%$ Pozzolan ash in a gradient temperature furnace at temperatures from 338 to $762^{\circ} \mathrm{C}$ for about $16 \mathrm{~h}$ : (a) $338^{\circ} \mathrm{C}<\mathrm{T}<430^{\circ} \mathrm{C}$, (b) $365^{\circ} \mathrm{C}<\mathrm{T}$ $<498^{\circ} \mathrm{C}$, (c) $430^{\circ} \mathrm{C}<\mathrm{T}<562^{\circ} \mathrm{C}$, (d) $498^{\circ} \mathrm{C}<\mathrm{T}<622^{\circ} \mathrm{C}$, (e) $562^{\circ} \mathrm{C}<\mathrm{T}<690^{\circ} \mathrm{C}$, and (f) $622^{\circ} \mathrm{C}$ $<\mathrm{T}<762^{\circ} \mathrm{C}$ 


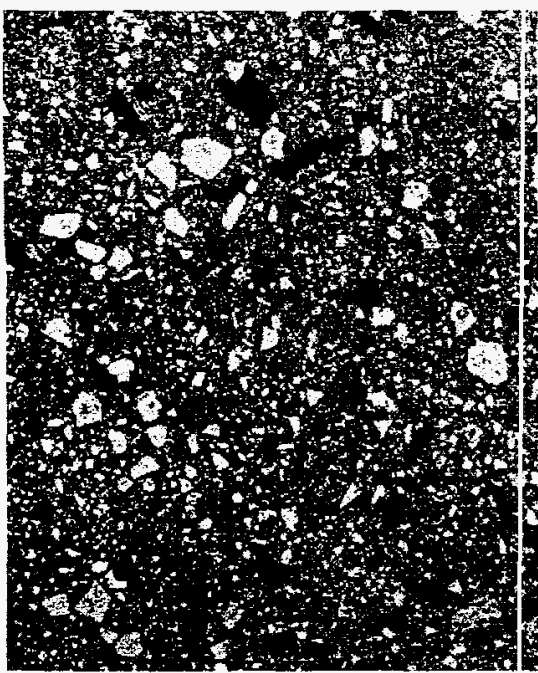

(a)

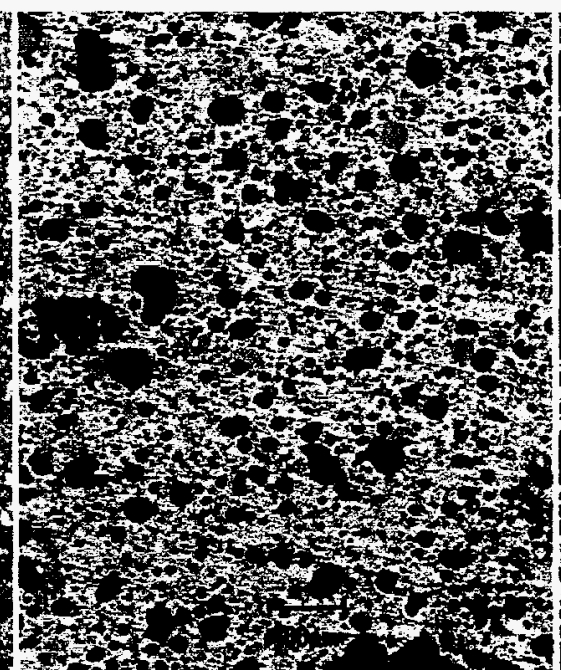

(b)

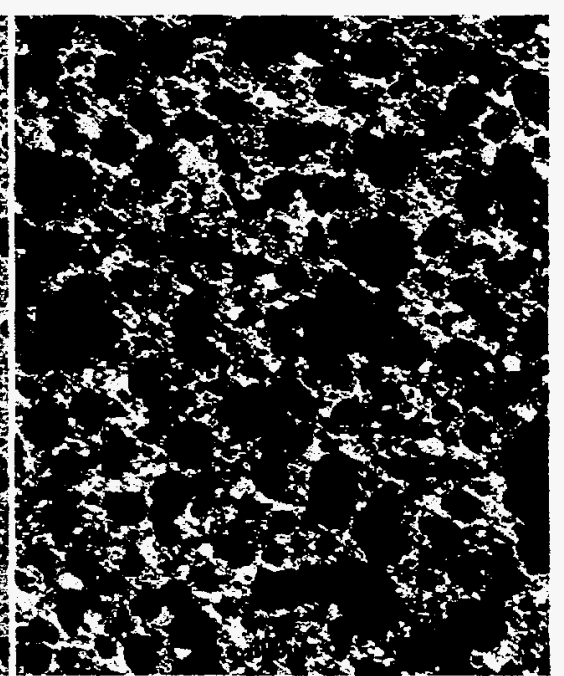

(c)

Figure 6. Optical micrographs shows the porosity of the heat-treated $80 \mathrm{wt} \%$ AVP-105 - $20 \mathrm{wt} \%$ Pozzolan ash samples at different temperatures: (a) $\sim 400^{\circ} \mathrm{C}$, (b) $\sim 595^{\circ} \mathrm{C}$, and (c) $\sim 640^{\circ} \mathrm{C}$

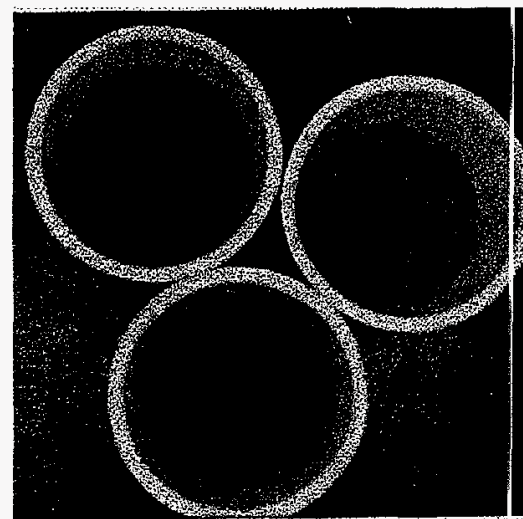

(a)

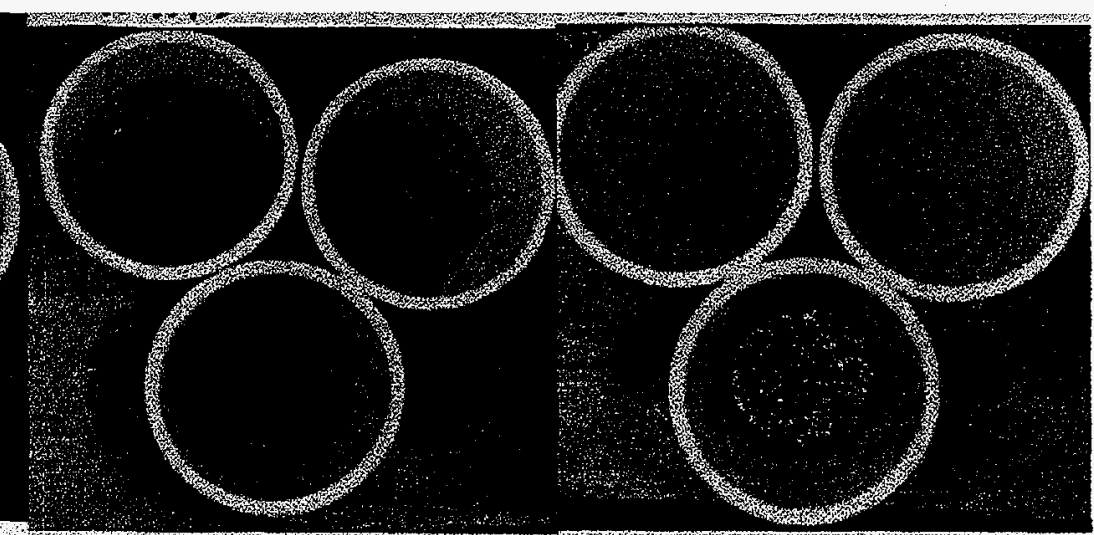

(b) (c)

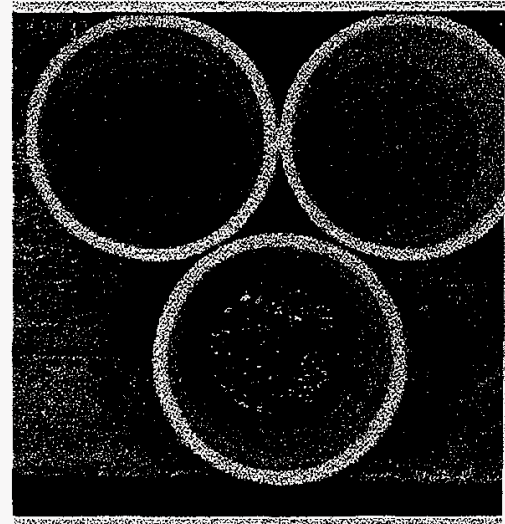

(d)

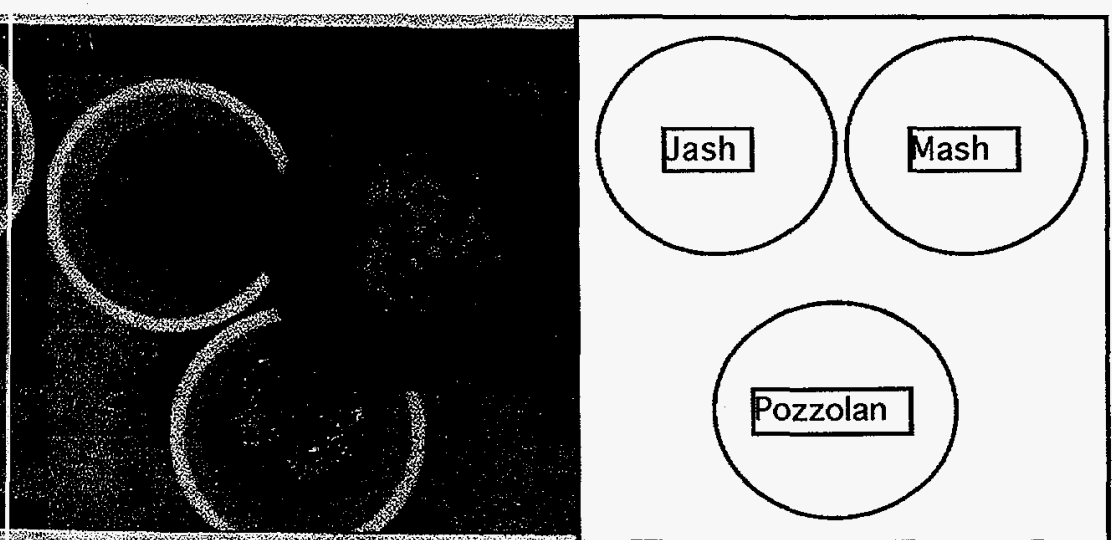

(e)

Figure 7. Sintering of three types of ashes: $\mathrm{J}$ ash, $\mathrm{M}$ ash, and Pozzolan ash, (20 wt\% loading) by AVP-100 frit : (a) the mixture; of AVP-100 frit with $20 \mathrm{wt} \% \mathrm{~J}$ ash, $\mathrm{M}$ ash, and Pozzolan ash prior to heat treatment, (b) $450^{\circ} \mathrm{C}-25 \mathrm{~min}$, (c) $450^{\circ} \mathrm{C}-1 \mathrm{~h}$, (d) $450^{\circ} \mathrm{C}-2 \mathrm{~h}$, and (e) $500^{\circ} \mathrm{C}-25 \mathrm{~min}$ (only the samples with $\mathrm{J}$ ash and $\mathrm{M}$ ash were treated at $500^{\circ} \mathrm{C}$ ). The ashes are marked on the drawing at the right corner 


\subsection{Iron Vanadium Phosphate Frit}

The IVP glasses listed in Table V were fabricated at $1000^{\circ} \mathrm{C}$ in a similar manner as AVP glasses by simply replacing antimony with iron. It was found that the IVP-102 melt exhibited high volatility, and a high degree of crystallinity was found in the quenched IVP-101 glass. Therefore, only the IVP-100, IVP-103, and IVP-104 frits were chosen to be used in the ash-sintering evaluation. With a $20 \mathrm{wt} \%$ Pozzolan ash loading, the lowest obtainable sintering temperature was determined to be $500^{\circ} \mathrm{C}$, and was obtained using the IVP-104 frit. Comparing the ash-sintering results under the same conditions of ash loading and type (Pozzolan ash in this case), the AVP-105 frit was found to sinter at a significantly lower temperature than the IVP-104 frit.

Table V. Iron vanadium phosphate frit compositions in wt $\%$

\begin{tabular}{|l|c|c|c|c|c||}
\hline & IVP-100 & IVP-101 & IVP-102 & IVP-103 & IVP-104 \\
\hline $\mathrm{CaF}_{2}$ & 0.00 & 0.00 & 5.00 & 0.00 & 0.00 \\
\hline $\mathrm{Fe}_{2} \mathrm{O}_{3}$ & 25.00 & 23.75 & 23.75 & 21.25 & 21.25 \\
\hline $\mathrm{P}_{2} \mathrm{O}_{5}$ & 40.00 & 38.00 & 38.00 & 34.00 & 34.00 \\
\hline $\mathrm{V}_{2} \mathrm{O}_{5}$ & 20.00 & 19.00 & 19.00 & 32.00 & 29.00 \\
\hline $\mathrm{ZnO}$ & 15.00 & 19.25 & 14.25 & 12.75 & 15.75 \\
\hline
\end{tabular}

Although the IVP frits studied so far had higher ash-sintering temperatures than those of the AVP frits, the IVP frits appeared to be less sensitive to the ash type. Figure 8 shows the results of J ash, $\mathrm{M}$ ash, and Pozzolan ashes sintered at various times and temperatures from $400^{\circ} \mathrm{C}$ to $800^{\circ} \mathrm{C}$ using IVP-100 frit. Although all the samples exhibited weight loss during sintering, no foaming was observed.

\subsection{Tin Zinc Phosphate Frit}

The TZP frits were fabricated between $750^{\circ} \mathrm{C}$ and $1100^{\circ} \mathrm{C}$. Table VI summarizes the TZP frit compositions investigated. TZP-100, TZP-101, TZP-102, and TZP-110 frits were highly crystallized and not included in the ash-sintering evaluation. TZP-103 was shown to sinter Pozzolan ash ( $20 \mathrm{wt} \%$ ash loading) at $350^{\circ} \mathrm{C}$ for $1 \mathrm{~h}$. Figure 9 shows the heat-treated samples $\left(350^{\circ} \mathrm{C}\right.$ for $1 \mathrm{~h}$ and $380^{\circ} \mathrm{C}$ for $1 \mathrm{~h}$ ) of TZP-103 frit with $20 \mathrm{wt} \%$ of Pozzolan ash, U of M ash, M ash, and $\mathrm{J}$ ash. In the remaining frit evaluations, $\mathrm{U}$ of $\mathrm{M}$ ash was used, which, based on previous observations, appeared to be slightly more difficult to sinter than Pozzolan ash, yet not as difficult as $\mathrm{M}$ ash or $\mathrm{J}$ ash.

The $U$ of $M$ ash sintering data showed that TZP-107 frit exhibited the lowest $T_{S}$ among all TZP frits studied. The $\mathrm{T}_{\mathrm{S}}$ for $20 \mathrm{wt} \% \mathrm{U}$ of $\mathrm{M}$ ash was $350^{\circ} \mathrm{C}$. Figure 10 shows the $2 \mathrm{~h}$ gradient temperature treated TZP-107 frit with $20 \mathrm{wt} \% \mathrm{U}$ of $\mathrm{M}$ ash from $\sim 340$ to $\sim 630^{\circ} \mathrm{C}$. In this case, the frit had a particle size distribution from 150 to $210 \mu \mathrm{m}$. The results demonstrated that the ash was sintered at temperatures as low as $\sim 340^{\circ} \mathrm{C}$, which can be seen in Figure 10(a). White droplets that are readily observable on the surface of the sintered ash where the fused frit particles that had a $\mathrm{T}_{\mathrm{g}}$ lower than $250^{\circ} \mathrm{C}$. a At higher temperatures, the ash was sintered without foaming, as demonstrated in Figure 10(b-c).

a The $T_{g}$ was estimated based on the observation that significant deformation of the quenched $\mathrm{TZP}-107$ frit was found at $250^{\circ} \mathrm{C}$. 


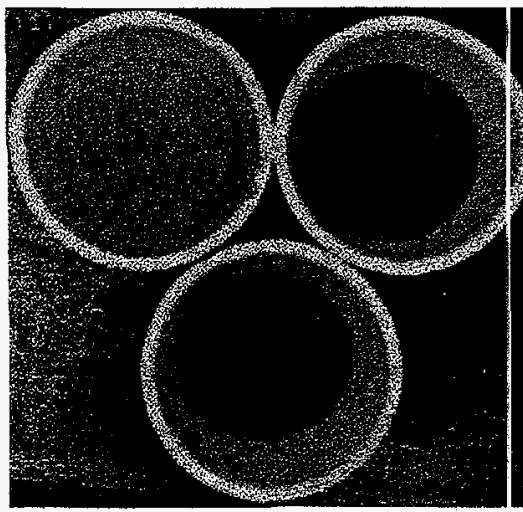

(a)

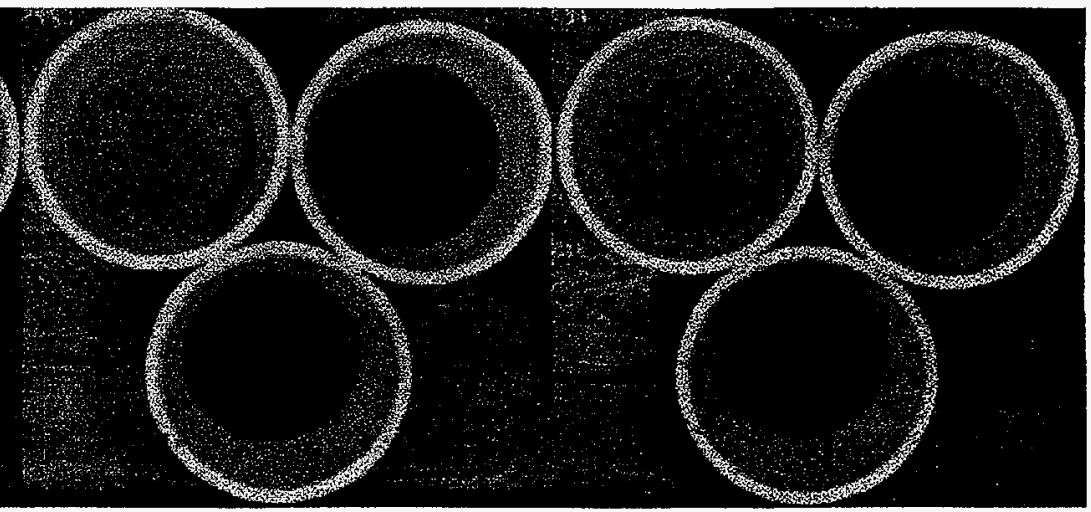

(b)

(c)

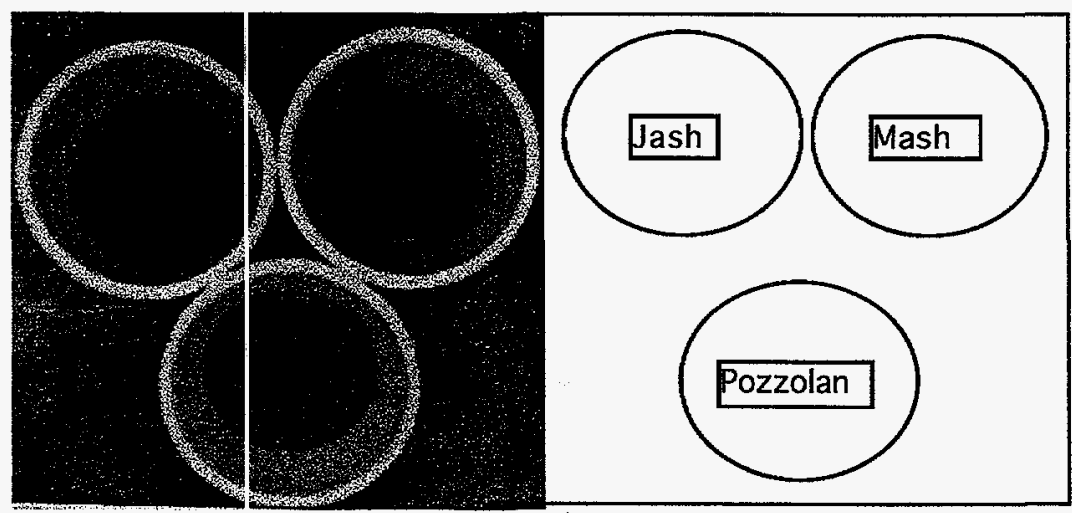

(d)

Figure 8. Sintering three types of ashes, $\mathrm{J}$ ash, $\mathrm{M}$ ash, and Pozzolan ash ( $20 \mathrm{wt} \%$ loading) by IVP-100 frit: (a) $450^{\circ} \mathrm{C}-18 \mathrm{l}$, (b) $480^{\circ} \mathrm{C}-2 \mathrm{~h}, 500^{\circ} \mathrm{C}-1 \mathrm{~h}, 520^{\circ} \mathrm{C}-20 \mathrm{~min}, 540^{\circ} \mathrm{C}-40 \mathrm{~min}$, and $600^{\circ} \mathrm{C}-1 \mathrm{~h}$, (d) $620^{\circ} \mathrm{C}-1 \mathrm{~h}$, and (e) $600^{\circ} \mathrm{C}-1 \mathrm{~h}$ and $700^{\circ} \mathrm{C}-1 \mathrm{~h}$ (the heat-treatment was continuous for each sample and the time cited at a given temperature was cumulative), The ashes are marked on the drawing at the bottom right corner

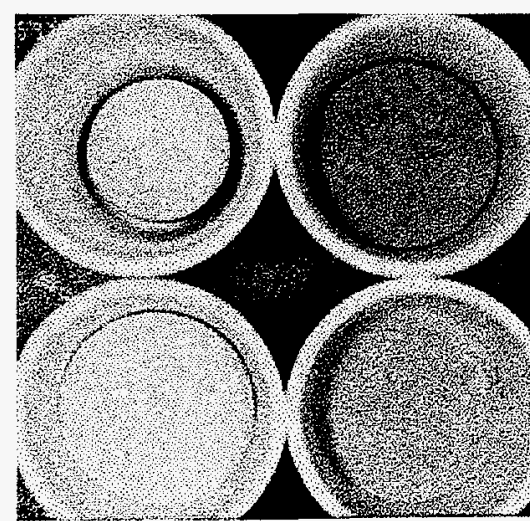

(a)

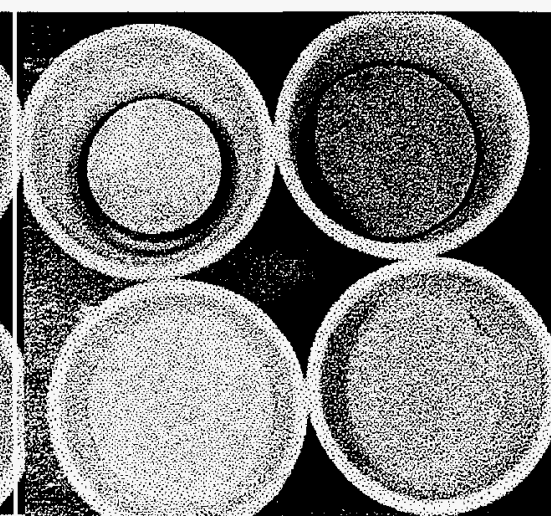

(b)

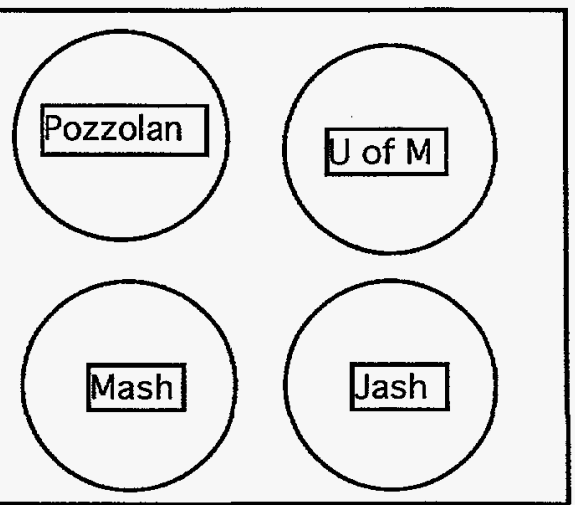

Jash

Figure 9. Sintering of Pozzolan ash, $U$ of $M$ ash, $M$ ash, and $J$ ash, with TZP-103 frit (20 wt\% ash loading): (a) $350^{\circ} \mathrm{C}-1 \mathrm{~h}$ and (b) $380^{\circ} \mathrm{C}-1 \mathrm{~h}$. The ashes are marked on the drawing at the right 
Table VI. Tin zinc phosphate frit compositions wt $\%$

\begin{tabular}{||l|l|l|l|l|l|l|l|l|l|l|l||}
\hline \hline & $\begin{array}{l}\text { TZP- } \\
100\end{array}$ & $\begin{array}{l}\text { TZP- } \\
101\end{array}$ & $\begin{array}{l}\text { TZP- } \\
102\end{array}$ & $\begin{array}{l}\text { TZP- } \\
103\end{array}$ & $\begin{array}{l}\text { TZP- } \\
104\end{array}$ & $\begin{array}{l}\text { TZP- } \\
105\end{array}$ & $\begin{array}{l}\text { TZP- } \\
106\end{array}$ & $\begin{array}{l}\text { TZP- } \\
107\end{array}$ & $\begin{array}{l}\text { TZP- } \\
108\end{array}$ & $\begin{array}{l}\text { TZP- } \\
109\end{array}$ & $\begin{array}{l}\text { TZP- } \\
110\end{array}$ \\
\hline $\mathrm{Al}_{2} \mathrm{O}_{3}$ & 0.00 & 0.00 & 0.00 & 0.00 & 0.00 & 0.00 & 0.00 & 0.00 & 0.00 & 3.57 & 5.61 \\
\hline $\mathrm{F}$ & 0.00 & 0.00 & 0.00 & 0.00 & 0.00 & 0.00 & 0.00 & 1.60 & 2.60 & 2.58 & 2.49 \\
\hline $\mathrm{P}_{2} \mathrm{O}_{5}$ & 40.98 & 35.23 & 36.86 & 45.69 & 47.74 & 55.60 & 64.99 & 59.77 & 51.82 & 51.44 & 62.11 \\
\hline $\mathrm{SnO}$ & 38.88 & 44.57 & 34.97 & 37.94 & 28.31 & 31.65 & 25.70 & 28.36 & 30.73 & 30.51 & 23.58 \\
\hline $\mathrm{ZnO}$ & 20.14 & 20.20 & 28.17 & 16.37 & 23.95 & 12.75 & 9.31 & 10.28 & 14.85 & 11.90 & 6.20 \\
\hline
\end{tabular}

However, using the same type of ash with the same particle size and ash loading, a completely different microstructures developed from finer heat treatment with finer TZP-107 frit particles (75 to $150 \mu \mathrm{m}$ ). The sample was heat-treated in the same temperature gradient furnace for $2 \mathrm{~h}$. Foaming was significant and covered the entire temperature region from $\sim 340^{\circ} \mathrm{C}$ to $\sim 630^{\circ} \mathrm{C}$ (see Figure 11). The observed frit size effect on ash foaming during sintering may be related to the fact that finer frit powder was easier to fuse the ash together [see Equation (1)] resulting in a closure of porosity, which prevented the removal of off-gas products.

\subsection{Soda-lime Silicate Frit}

This test evaluated an R-6 soda-lime glass frit ( 73 wt $\% \mathrm{SiO}_{2}, 15$ wt $\% \mathrm{Na}_{2} \mathrm{O}, 4$ wt\% $\mathrm{MgO}, 7$ wt\% $\mathrm{CaO}$, and $1 \mathrm{wt} \% \mathrm{Al}_{2} \mathrm{O}_{3}$ ). Several particle size fractions were prepared by grinding and sieving. The frit was mixed with $15 \mathrm{wt} \% \mathrm{~J}$ ash, placed in alumina boats, and heat-treated in a gradient furnace for $2 \mathrm{~h}$. Boats were then mounted in epoxy resin, sectioned longitudinally, and viewed to identify sintering and bubble formation.

In the absence of ash, the R- 6 frit of $850-1000 \mu \mathrm{m}$ particle size began to sinter at $740^{\circ} \mathrm{C}$. As sintering between individual particles continued, shrinkage started at $745^{\circ} \mathrm{C}$, and porosity began to close above $765^{\circ} \mathrm{C}$. When the test was repeated with a smaller particle size, $425-850 \mu \mathrm{m}$, sintering began at $710^{\circ} \mathrm{C}$, and porosity began to close above $725^{\circ} \mathrm{C}$.

For $\mathbf{J}$ ash ( $15 \mathrm{wt} \%$ ) encapsulation in R-6 frit, two frit particle size fractions, 425-850 $\mu \mathrm{m}$ and 850 $1000 \mu \mathrm{m}$, were tested within the temperature interval from $750^{\circ} \mathrm{C}$ to $940^{\circ} \mathrm{C}$. No volume expansion was observed within this temperature span, although bubbles formed above $925^{\circ} \mathrm{C}$. Sintering began at approximately $870^{\circ} \mathrm{C}$, and the open porosity began to close at $915^{\circ} \mathrm{C}-150^{\circ} \mathrm{C}$ to $190^{\circ} \mathrm{C}$ above the corresponding temperature for the pure frit. This increase in sintering temperature can be attributed to a surface interaction between frit and ash. Because $\mathrm{T}_{S}>800^{\circ} \mathrm{C}$, further testing of ash encapsulation in R-6 glass was discontinued.

The R- 6 glass was applied to encapsulation of the SS\&C mixture (20 wt\%), using two particle size fractions, $425-1000 \mu \mathrm{m}$ and $<75 \mu \mathrm{m}$. At $740^{\circ} \mathrm{C}$, which was the sample cold end temperature, the coarse-particle frit was partly sintered, with open porosity. Porosity began to close and shrinkage started at $880^{\circ} \mathrm{C}$, which is too high a temperature for in-can encapsulation. At $970^{\circ} \mathrm{C}$ (at an approximate viscosity of $7 \times 10^{2} \mathrm{~Pa} \cdot \mathrm{s}$ ), the frit reacted with $\mathrm{Ca}$ metal, turning black and producing large bubbles. This was probably a result of the reaction $3 \mathrm{Ca}+2 \mathrm{SiO}_{2}-->3 \mathrm{CaO}+\mathrm{Si}+\mathrm{SiO}$. The elemental Si produced the black color and the gaseous $\mathrm{SiO}$ the bubbles. Bubbles began to form around $\mathrm{Ca}$ particles at $900^{\circ} \mathrm{C}$. Gas was probably generated by the reaction $\mathrm{Ca}+\mathrm{SiO}_{2}-\rightarrow \mathrm{CaO}+$ $\mathrm{SiO}$, which does not produce discoloration. 


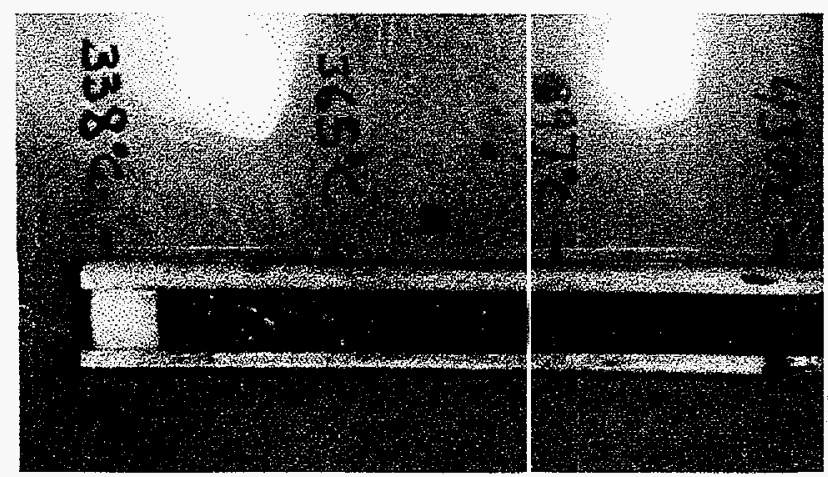

(a)

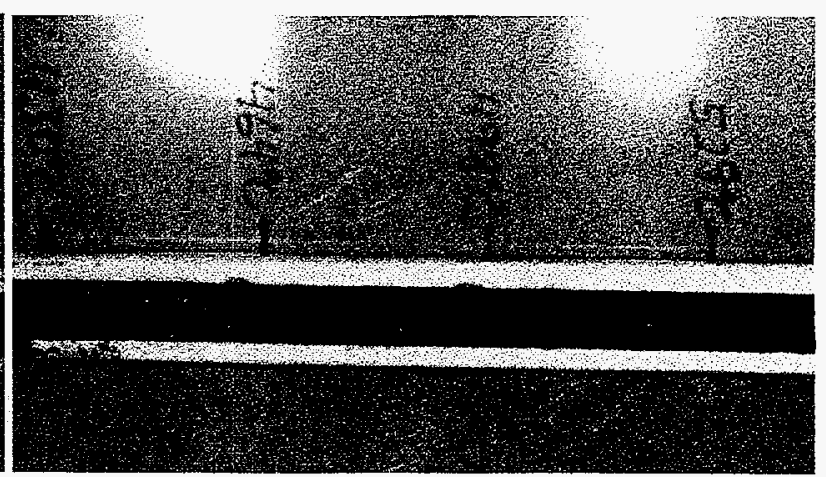

(b)
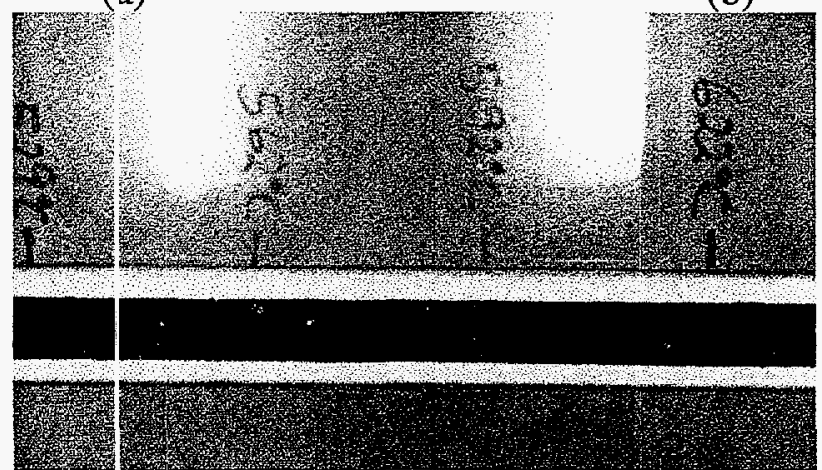

(c)

Figure 10. Coarse (150 to $210, \mathrm{um}$ ) TZP-107 frit with $20 \mathrm{wt} \% \mathrm{U}$ of $\mathrm{M}$ ash in a gradient furnace for $2 \mathrm{~h}$ : (a) $338^{\circ} \mathrm{C}<\mathrm{T}<440^{\circ} \mathrm{C}$, (b) $430^{\circ} \mathrm{C}<\mathrm{T}<562^{\circ} \mathrm{C}$, and (c) $520^{\circ} \mathrm{C}<\mathrm{T}<640^{\circ} \mathrm{C}$

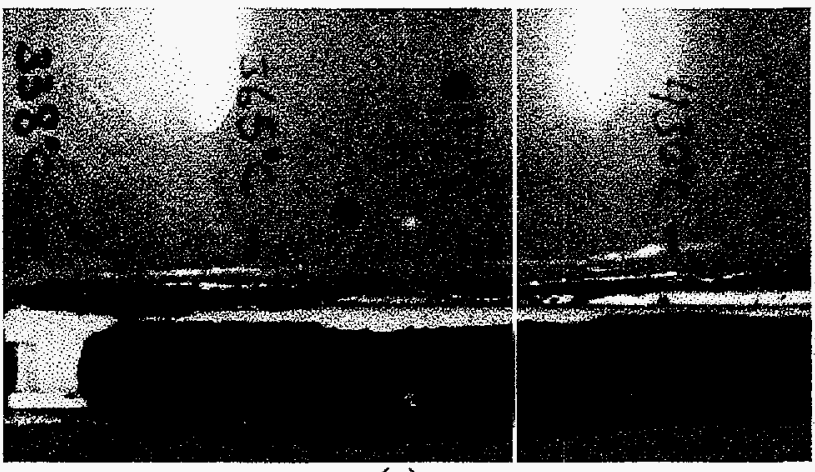

(a)

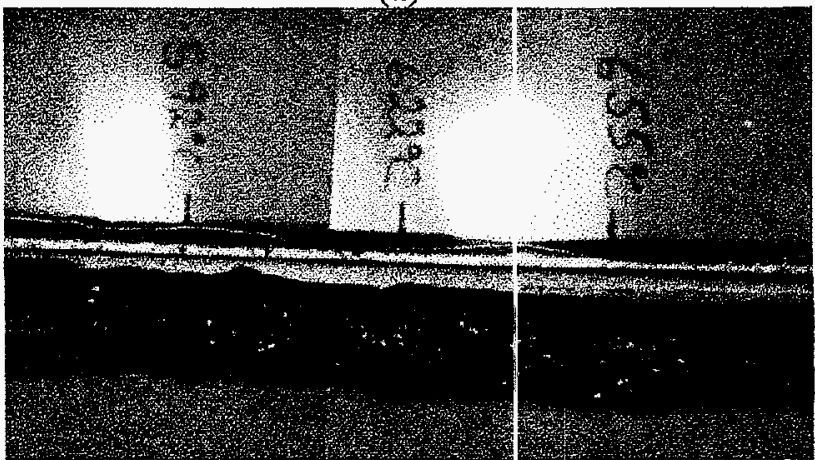

(c)

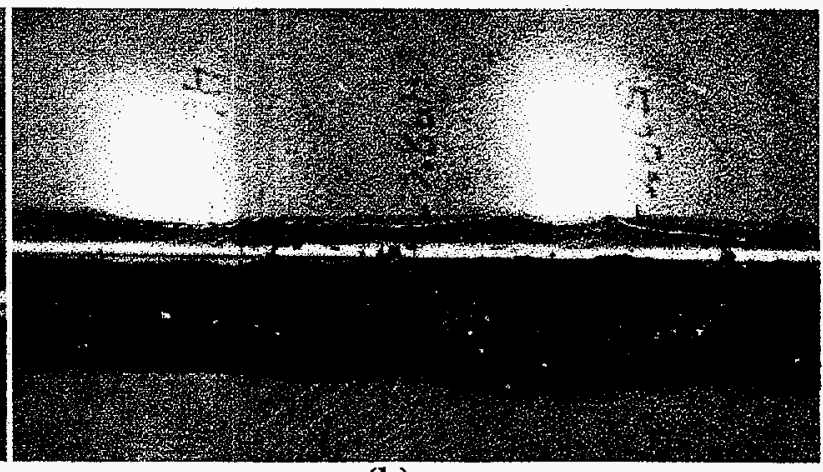

(b)

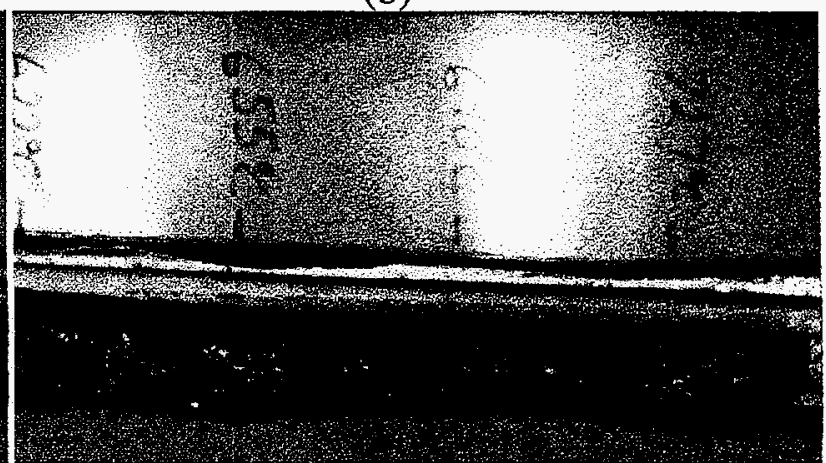

(d)

Figure 11. Fine ( 75 to $150 \mu \mathrm{m}$ ) TZP-107 frit with $20 \mathrm{wt} \% \mathrm{U}$ of $\mathrm{M}$ ash in a gradient furnace for $2 \mathrm{~h}$ : (a) $338^{\circ} \mathrm{C}<\mathrm{T}<448^{\circ} \mathrm{C}$, (b) $430^{\circ} \mathrm{C}<\mathrm{T}<545^{\circ} \mathrm{C}$, and (c) $545^{\circ} \mathrm{C}<\mathrm{T}<672^{\circ} \mathrm{C}$, and (d) $620^{\circ} \mathrm{C}<\mathrm{T}<748^{\circ} \mathrm{C}$ 
When frit with particles $<75 \mu \mathrm{m}$ was used, the mixture began to shrink at $660^{\circ} \mathrm{C}$, corresponding to a frit viscosity $4.5 \times 10^{7} \mathrm{~Pa} \cdot \mathrm{s}$. No discoloration occurred up to $830^{\circ} \mathrm{C}$, the temperature at the hot end of the sample, and no bubbles associated with $\mathrm{Ca}$ particles were observed throughout the sample (i.e., up to $830^{\circ} \mathrm{C}$ ). The actual surface viscosity was probably reduced due to the interaction with $\mathrm{CaF}_{2}$. This interaction may have also altered the sintering mechanism. As Table VII shows, R- 6 frit with particles $>75 \mu \mathrm{m}$ is not a good candidate for Rocky Flats waste encapsulation because its high sintering temperature when in contact with the waste.

Table VII. Sintering and foaming temperatures for different wastes and soda-lime silicate frit particle sizes

\begin{tabular}{||l|l|l|l||}
\hline Particle Size $(\mu \mathrm{m})$ & Waste $(w t \%)$ & $T_{S}\left({ }^{\circ} \mathrm{C}\right)$ & $T_{E}\left({ }^{\circ} \mathrm{C}\right)$ \\
\hline $850-1000$ & $-(0)$ & 765 & - \\
\hline $425-850$ & $-(0)$ & 725 & - \\
\hline $850-1000$ & JA+G (15) & 915 & $>940$ \\
\hline $425-850$ & JA+G (15) & 915 & $>940$ \\
\hline $425-1000$ & SS\&C (20) & 880 & 970 \\
\hline$<75$ & SS\&C (20) & 660 & 830 \\
\hline \multicolumn{4}{|l|}{ JA - J ash }
\end{tabular}

\subsection{Alkali Borosilicate Frit}

This test evaluated a BSi- 1 borosilicate glass frit $\left(60 \mathrm{wt} \% \mathrm{SiO}_{2}, 10 \mathrm{wt} \% \mathrm{~B}_{2} \mathrm{O}_{3}, 15 \mathrm{wt} \% \mathrm{Na}_{2} \mathrm{O}\right.$, $5 \mathrm{wt} \% \mathrm{Li}_{2} \mathrm{O}, 5 \mathrm{wt} \% \mathrm{Al}_{2} \mathrm{O}_{3}$, and $5 \mathrm{wt} \% \mathrm{ZrO}_{2}$ ). Several particle size fractions were prepared by grinding and sieving. The frit was mixed with $15 \mathrm{wt} \% \mathrm{~J}$ ash or $20 \mathrm{wt} \%$ Pozzolan with graphite or active carbon, placed in alumina boats, and heat-treated in a gradient furnace for $2 \mathrm{~h}$. Boats were then mount in epoxy resin, sectioned longitudinally, and viewed to identify sintering and bubble formation.

For encapsulation of $20 \mathrm{wt} \%$ Pozzolan ash with graphite in the BSi-1 glass, three particle size fractions of frit were used: $<75 \mu \mathrm{m}, 75-425 \mu \mathrm{m}$, and $425-1000 \mu \mathrm{m}$. With the finest frit $(<75 \mu \mathrm{m})$, the sample appeared to have sintered at the cold end $\left(630^{\circ} \mathrm{C}\right)$, with the occurrence of sporadic small bubbles. At $680^{\circ} \mathrm{C}$, bubbles became larger (up to $3 \mathrm{~mm}$ in diameter). At $720^{\circ} \mathrm{C}$, the sample expanded and turned into foam, which began to collapse above $795^{\circ} \mathrm{C}$. With the medium size frit (75-425 $\mu \mathrm{m})$, no foaming occurred throughout the temperature interval spanned by the sample $\left(630^{\circ} \mathrm{C}\right.$ to $795^{\circ} \mathrm{C}$ ). The sample appeared to have sintered above $680^{\circ} \mathrm{C}$, where the porosity appeared closed (sintering began at approximately $645^{\circ} \mathrm{C}$ ). The coarse frit $(425-1000 \mu \mathrm{m})$ began to shrink at $740^{\circ} \mathrm{C}$ and generated bubbles at $770^{\circ} \mathrm{C}$. No foaming occurred up to $795^{\circ} \mathrm{C}$ (the sample hot end). Pozzolan frit with activated carbon was also tested under identical conditions, except that the sample hot end reached $965^{\circ} \mathrm{C}$. In this sample, bubbles appeared at $740^{\circ} \mathrm{C}$, and extensive foaming started at $770^{\circ} \mathrm{C}$ and collapsed above $890^{\circ} \mathrm{C}$.

Table VIII summarizes the encapsulation results for ash and SS\&C in BSi-1 frit. Encapsulation of SS\&C in the BSi-1 frit consisting of $425-1000 \mu \mathrm{m}$ particle size resulted in black discoloration and extensive bubbling by $770^{\circ} \mathrm{C}$, at a predicted viscosity of approximately $4 \times 10^{3} \mathrm{~Pa} \cdot \mathrm{s}$. Sporadic large bubbles without discoloration occurred at $690^{\circ} \mathrm{C}$ (viscosity $7.3 \times 10^{4} \mathrm{~Pa} \cdot \mathrm{s}$ ). With $<75 \mu \mathrm{m}$ frit, the sample was fully sintered at the cold end $\left(670^{\circ} \mathrm{C}\right)$, which is as expected because the predicted 
sintering temperature of pure frit is approximately $590^{\circ} \mathrm{C}$ (viscosity $10^{7} \mathrm{~Pa} \cdot \mathrm{s}$ ). Discoloration due to $\mathrm{Ca}$ occurred at $785^{\circ} \mathrm{C}$. Butbles were associated with all $\mathrm{Ca}$ particles present in the samples. It is possible that $\mathrm{SiO}$ can be produced in $\mathrm{BSi}-1$ glass at temperatures below $670^{\circ} \mathrm{C}$. The large difference between the commencement of bubble generation (more than $200^{\circ} \mathrm{C}$ ) in $\mathrm{R}-6$ and $\mathrm{BSi}-1$ is probably due to the difference in activity of $\mathrm{SiO}_{2}$ in these two frits. $\mathrm{MgO}$ particles (porous $\mathrm{MgO}$ sand was used) floated on the surface above $690^{\circ} \mathrm{C}$.

Table VIII. Sintering and foaming temperatures for different wastes and alkali borosilicate frit particle sizes

\begin{tabular}{||l|l|l|l||}
\hline Particle Size $(\mu \mathrm{m})$ & Waste Type $($ wt $\%)$ & $\mathrm{T}_{S}\left({ }^{\circ} \mathrm{C}\right)$ & $\mathrm{T}_{\mathrm{F}}\left({ }^{\circ} \mathrm{C}\right)$ \\
\hline $425-1000$ & PA+AC(20) & 670 & 770 \\
\hline $425-1000$ & PA+G(20) & 740 & $>795$ \\
\hline $75-425$ & PA+G(20) & 689 & $>795$ \\
\hline$<75$ & PA+G $(20)$ & $<630$ & 720 \\
\hline $425-1000$ & SS\&C $(20)$ & $640 *$ & 770 \\
\hline$<75$ & SS\&C $(20)$ & $590 *$ & 715 \\
\hline
\end{tabular}

\subsection{Alkali Borate Frit}

Three AB glasses were fabricated from a combination of Borax $5 \mathrm{Mol}$ (supplied by U.S. Borax, Inc.), boric acid, sodium carb onate, and sodium fluoride. Melts were conducted at $1000^{\circ} \mathrm{C}$ for $1 \mathrm{~h}$ then quenched onto a stainlesis steel plate. Frits were prepared by grinding the quenched glasses and sieving to -140 mesh $(\leq 105 \mu \mathrm{m})$. The compositions prepared are summarized in Table IX.

Table IX. Compositions of alkali borate frits (wt\%)

\begin{tabular}{||l|l|l|l|l|}
\hline Component & AB-106 & AB-067 & AB-109 & Source \\
\hline $\mathrm{B}_{2} \mathrm{O}_{3}$ & 60.00 & 68.40 & 90.00 & borax, $\mathrm{H}_{3} \mathrm{BO}_{3}$ \\
\hline $\mathrm{Na}_{2} \mathrm{O}$ & 30.00 & 25.60 & 0.00 & borax \\
\hline $\mathrm{NaF}$ & 10.00 & 6.00 & 10.00 & $\mathrm{NaF}$ \\
\hline
\end{tabular}

The frit/ash sinterability was evaluated by mixing $10.0 \mathrm{~g}$ of $\mathrm{AB}$ frit, $2.0 \mathrm{~g}$ Pozzolan ash, and $0.5 \mathrm{~g}$ activated carbon in an aluminit crucible and heating at either $400^{\circ} \mathrm{C}$ or $500^{\circ} \mathrm{C}$ for $1 \mathrm{~h}$. Significant sintering accompanied by shrinkage of the ash and no foaming was observed for all three frits at $500^{\circ} \mathrm{C}$. At lower temperature, , little or no sintering was observed. Only the AB-067 frit produced a sintered body that was free of cracks after heating at $500^{\circ} \mathrm{C}$, as demonstrated by Figure 12 , which shows the $500^{\circ} \mathrm{C}$ sintered $\mathrm{AB}-067$ frit/ash removed from its crucible.

The temperature and composition dependence of the viscosity for alkali borate glasses is somewhat complex. For pure $\mathrm{B}_{2} \mathrm{O}_{3}$ at $500^{\circ} \mathrm{C}$, the viscosity $\left(\approx 10^{3} \mathrm{~Pa} \cdot \mathrm{s}\right)$ is lower than silicates, borosilicates, and even $\mathrm{P}_{2} \mathrm{O}_{5}$; however, at lower temperatures, $\mathrm{P}_{2} \mathrm{O}_{5}$ is comparable or even lower in viscosity than $\mathrm{B}_{2} \mathrm{O}_{3}$ [11]. The addition of alkali (e.g., $\mathrm{Na}_{2} \mathrm{O}$ ) to $\mathrm{B}_{2} \mathrm{O}_{3}$, initially causes the transformation of some of the weakly linked bojoxyl rings to tetraborate entities that contain 4-coordinate network 
forming $\mathrm{BO}_{4}$ groups at low temperatures $\left(<900^{\circ} \mathrm{C}\right)$. At higher temperatures, network breaking non-bridging oxygen (NBO) sites, as opposed to network forming $\mathrm{BO}_{4}$ groups, are believed to form with increasing alkali content. Thus, at $1000^{\circ} \mathrm{C}$, the viscosity of $\mathrm{B}_{2} \mathrm{O}_{3}$ decreases rapidly from $\approx 10 \mathrm{~Pa} \cdot \mathrm{s}$ with increasing alkali content, while at $500^{\circ} \mathrm{C}$, the viscosity initially increases rapidly from $\approx 10^{3.3} \mathrm{~Pa} \cdot \mathrm{s}$ with increasing alkali. The alkali borate viscosity at low temperatures generally goes through a maximum before beginning to decrease with further additions of alkali resulting from the ultimate formation of NBO sites [12]. Clearly, though, for the alkali (fluoro)borate compositions used here, the viscosity remains sufficiently low enough with increasing alkali (and fluoride) concentration that sintering can occur. However, at $400^{\circ} \mathrm{C}$ and lower, the viscosity of alkali borate frits is too high over a broad range of compositions to allow for a satisfactory rate of sintering. This is in agreement with the structural model for borate glasses and the corresponding increase in viscous flow activation energy with decreasing temperature [11].

\subsection{DISCUSSION AND RECOMMENDATION}

The current flowsheet for vitrification of RFETS ash and SS\&C is given in Figure 13. This process must be conducted within a $4 \mathrm{~h}$ cycle time in existing equipment at RFETS to meet the aggressive treatment schedule. The off-gas equipment currently installed at RFETS limits the process temperature to $\leq 800^{\circ} \mathrm{C}$. With this in mind, frit selection was made based on the ability of the frits to process ash and SS\&C below $800^{\circ} \mathrm{C}$ with cycle times shorter than $4 \mathrm{~h}$. In addition, the ability to vitrify the diverse waste stream with minimum probability of process upset is required. To avoid foaming (a process upset) ash vitrification should be performed in a temperature region of reduced off-gas. The most favorable temperature ranges for this are between $200^{\circ} \mathrm{C}$ and $400^{\circ} \mathrm{C}$ and between $600^{\circ} \mathrm{C}$ and $800^{\circ} \mathrm{C}$.

Of the frits evaluated, the TZP's appear to be best suited for ash agglomeration below $400^{\circ} \mathrm{C}$. Sintering temperatures as low as $340^{\circ} \mathrm{C}$ were demonstrated with the TZP- 107 frit. No other frit demonstrated the capability of sintering below $390^{\circ} \mathrm{C}$. If higher temperature $\left(600^{\circ} \mathrm{C}\right.$ to $\left.800^{\circ} \mathrm{C}\right)$ processing of ash is required to meet the newly defined stability and/or recoverability criteria, the ABS glass family is favored. These glasses can be easily tailored to meet processing and product quality restrictions using existing glass property databases. Preliminary tests with BSi-1 confirm the ability to develop a glass frit for processing in the higher temperature range. The durabilities of ABS glasses are generally higher than those of the lower temperature phosphate-based glasses.

It is recommended that TZP-107 and BSi-1 (ABS) glasses be selected as possible frit compositions for vitrification of both ash and SS\&C. Variability testing and composition refinement should be performed using both glass families. Variability testing will include frit composition refinement, study of tolerance to waste loading and composition variation, and time/temperature variations. It is further recommended that testing of $\mathrm{AB}, \mathrm{AVP}$, IVP, and SLS glass compositions not be pursued.

Since Rocky Flats ash vitrification will rely on densification via sintering as opposed to melt processing, methods to improve the sintering behavior for a given frit, regardless of specific composition, need to be further explored. One important parameter which influences sinterability and, as demonstrated here, foaming is the particle size of the frit. Going to smaller particle sizes may greatly increase the rate of sintering; however, the role particle size plays in controlling foaming needs to be more precisely determined. A higher theoretical density (lower porosity) after sintering for a given frit/ash combination could be obtained by increasing the density of the starting frit/ash charge in the can. Since no mechanical pressing operations are envisioned for this process, 


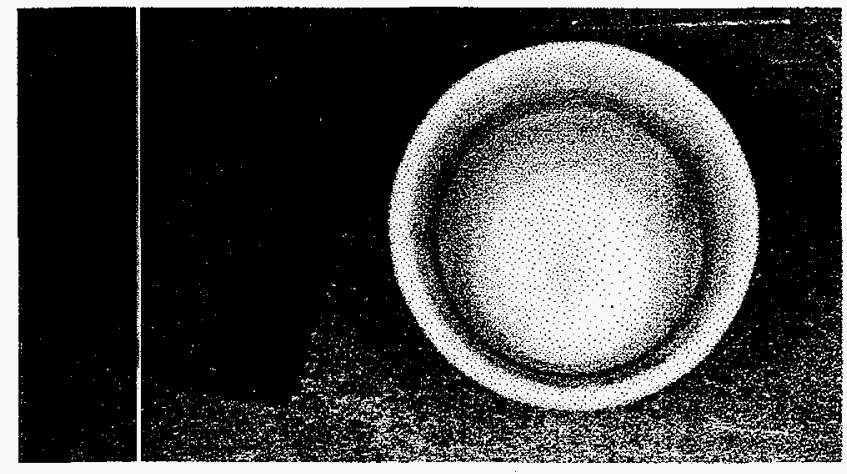

Figure 12. Pozzolan ash and activated carbon sintered at $500^{\circ} \mathrm{C}$ for $1 \mathrm{~h}$ using the $\mathrm{AB}-067$ frit. The sintered body (left) has been removed from the alumina crucible (right)

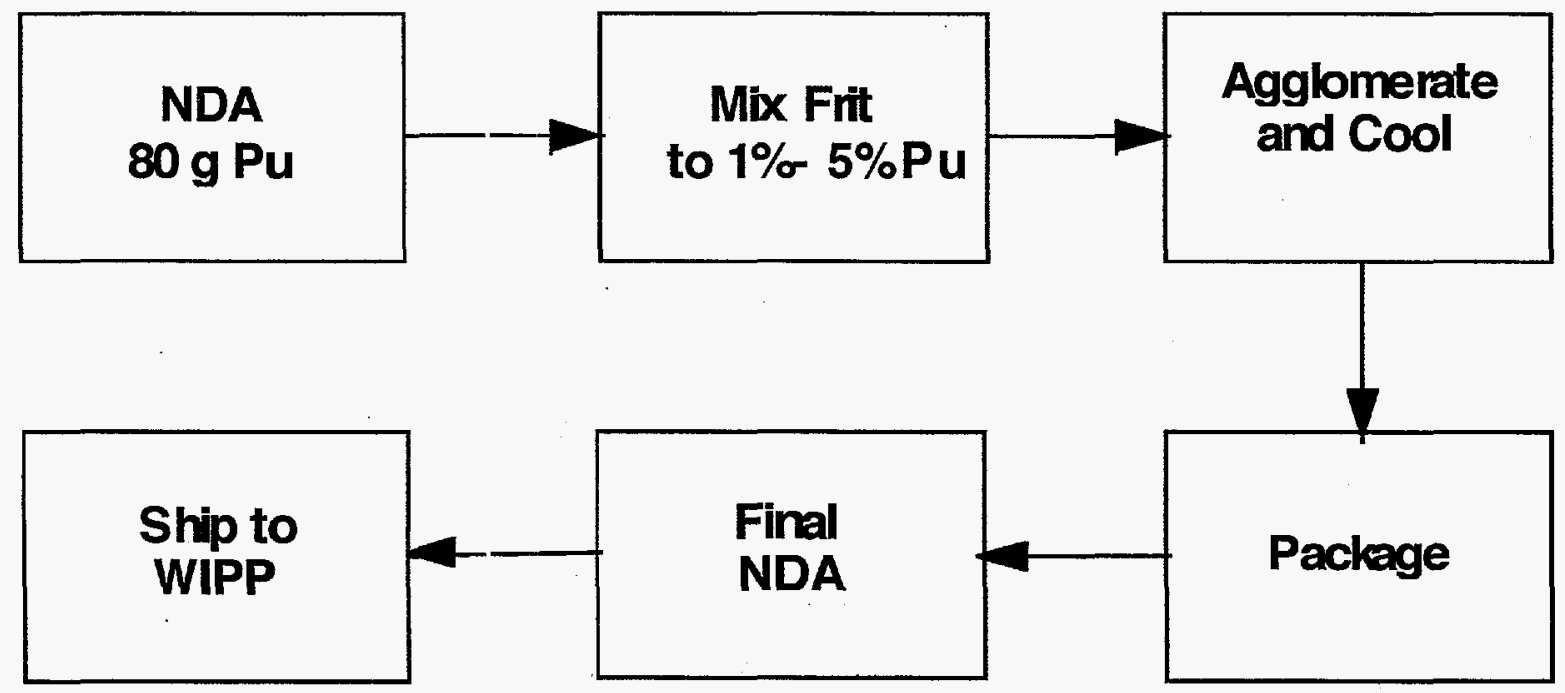

Figure 13. Process flowsheet for vitrification of ash and SS\&C 
one must rely obtaining maximal tap densities for the frit/ash powders. Generally, extremely fine and/or irregularly shaped particles do not flow or pack well due to their inherently high interparticle friction. Thus, both frit particle size and morphology will be critical issues that have not yet been addressed. This information will be important for providing potential frit vendors with the correct materials specifications.

\subsection{ACKNOWLEDGMENTS}

The authors would like to acknowledge the help received from several individuals in performing this research, preparing this document, and guidance of this study. We are grateful to Matt Stachnik, Steve Simon, and Michael Schweiger for there assistance in frit and sample fabrication and data evaluation. We thank Ben Peng for the off-gas/temperature characterization and Meiling Gong and Bob Barbara for ash composition analysis. We are indebted to Sue Gano for her masterful editing of this document. We wish to acknowledge all the support and guidance of Gerry Veazey and Ron Nakaoka. We thank Al Phillips, Tim Burns, and Mike Finney for their assistance in understanding the end-user needs. We would like to thank Robert McBroom (U.S. Borax, Inc.) for his technical discussions and for supplying us with Borax feed materials. The technical information on power plant fly ash characteristics and sources provided by J.D. Darab (Raytheon Engineers \& Constructors, Inc.) was most appreciated. We would like to thank Western Ash Company for supplying us with several samples of fly ash.

\subsection{REFERENCES}

1. "Criteria for Interim Safe Storage of Plutonium-Bearing Solid Materials," Addendum to the Department of Energy Implementation Plan for DNFSB 94-1 (November 1995).

2. "Additional Attractiveness Level E Criteria," Memorandum from E.J. McCallum, DOE NN-51 (July 1996).

3. Waste Acceptance Criteria for the Waste Isolation Pilot Plant, Rev. 5, DOE/WIPP-069 (April 1996).

4. J. L. Long, “Analysis of Incinerator Ash \& Heel," Internal Rocky Flats Job Report No. PER 1-74, DPA950348 dtd. January 4, 1974.

5. R. G. Behrens, E. C. Buck, N. L. Dietz, J. K. Bates, E. Van Deventer, and D. J. Chaiko, Characterization of Plutonium-Bearing Wastes by Chemical Analysis and Analytical Electron Microscopy, ANL-95/35, Argonne National Laboratory, Argonne, IL (September 1995).

6. D. B. Guralnik, Webster's New World Dictionary of the American Language, 2nd ed., William Collins + World Publishing, Cleveland (1976).

7. R.M. German, Powder Metallurgy Science, Metal Powders Industry Federation, Princeton (1984).

8. N. P. Bansal and R. H. Doremus, Handbook of Glass Properties, Academic Press, Orlando (1986).

9. M. Tomozawa and R. H. Doremus, Glass II, Treatise on Materials Science and Technology, Vol. 17, Academic Press, New York (1979).

10. P. Hrma, G. F. Piepel, M. J. Schweiger, D. E. Smith, D.-S. Kim, P. E. Redgate, J. D. Vienna, C. A. LoPresti, D. B. Simpson, D. K. Peeler, and M. H. Langowski, Property / Composition Relationships for Hanford High-Level Waste Glasses Melting at $1150^{\circ} \mathrm{C}$, PNL10359, Vol. 1 and 2, Pacific Northwest Laboratory, Richland, Washington (1994).

11. R. H. Doremus, Glass Science, John Wiley \& Sons, New York (1973).

12. W. Vogel, Chemistry of Glass, American Ceramic Society, Westerville, $\mathrm{OH}$ (1985). 


\subsection{APPENDIX}

Full-Scale Vollrath Container Test with PNNL Black Frit

Memo from Jc-Kael Luey (PNNL) to Gerry Veazey (LANL) dated May 17, 1997 discussing full-scale testing of ash encapsulation in Vollrath can and a PNNL iron borosilicate frit. 


\section{DON'T SAY IT --- Write It!}

DATE: May 17, 1997

TO: Gerry Veazey, LANL

FROM: Ja-Kael Luey, PNNL
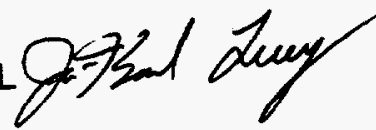

SUBJECT: FULL-SCALE VOLLRATH: PNNL BLACK FRIT WITH 20 WT\% ASH

On May 16, 1997, testing was initiated to measure the temperature profile of a full-scale Vollrath container filled with PNNL black frit (iron borosilicate frit) and $20 \mathrm{wt} \%$ ash (used a blast furnace ash that did not have any carbon content). The full container was placed into a furnace at $650^{\circ} \mathrm{C}$ and was instrumented in the same manner as a full-scale test performed on May 9. Preliminary results from this test are discussed below.

1. The attached plots show the frit with ash reached steady-state temperatures in an a mount of time ( 5 hours) comparable to results from the frit-only test. Data gaps during the first hour for the $20 \mathrm{wt} \%$ ash test were caused by an initial problem with the data acquisition system.

2. Unlike the results from tests in $600 \mathrm{ml}$ stainless steel beakers, the rate of temperature rise for the $20 \mathrm{wt} \%$ test was not consistently better than the test without ash. Further analysis of the data and final sample is needed to determine if this is scale related.

3. The initial observation of the final product shows that the top surface was agglomerated. The batch sample pulled away from the wall of the container an average of 0.25 ". Observation of the interior of the block will be done Monday after it has cooled.

4. The sample for the test was left in the furnace at $650^{\circ} \mathrm{C}$ for more than 20 hours. For the test without ash present, the container was left in the furnace for 6 hours. While longer time would not have drastically changed the final product for the frit-only test (the frit had slumped after 6 hours), it may have had an effect on the final product for this test. The longer time may have allowed the agglomeration process to proceed farther than it would have if the sample had been removed from he furnace earlier. Time at temperature is to be further evaluated during variability testing. 


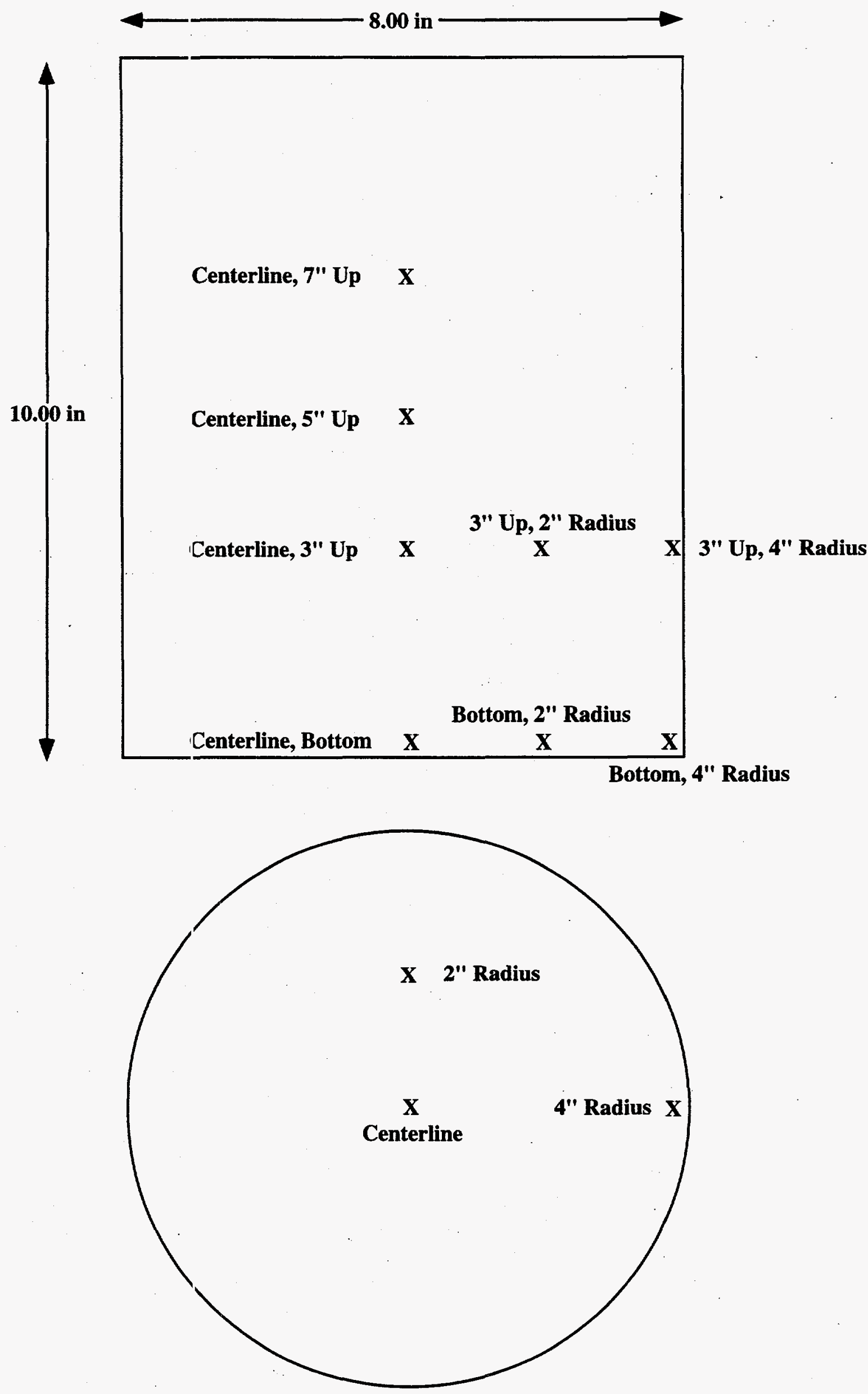




\section{TEMPERATURE PROFILES FOR VOLLRATH CONTAINER PNNL BLACK FRIT WITH DIFFERENT ASH LOADING}

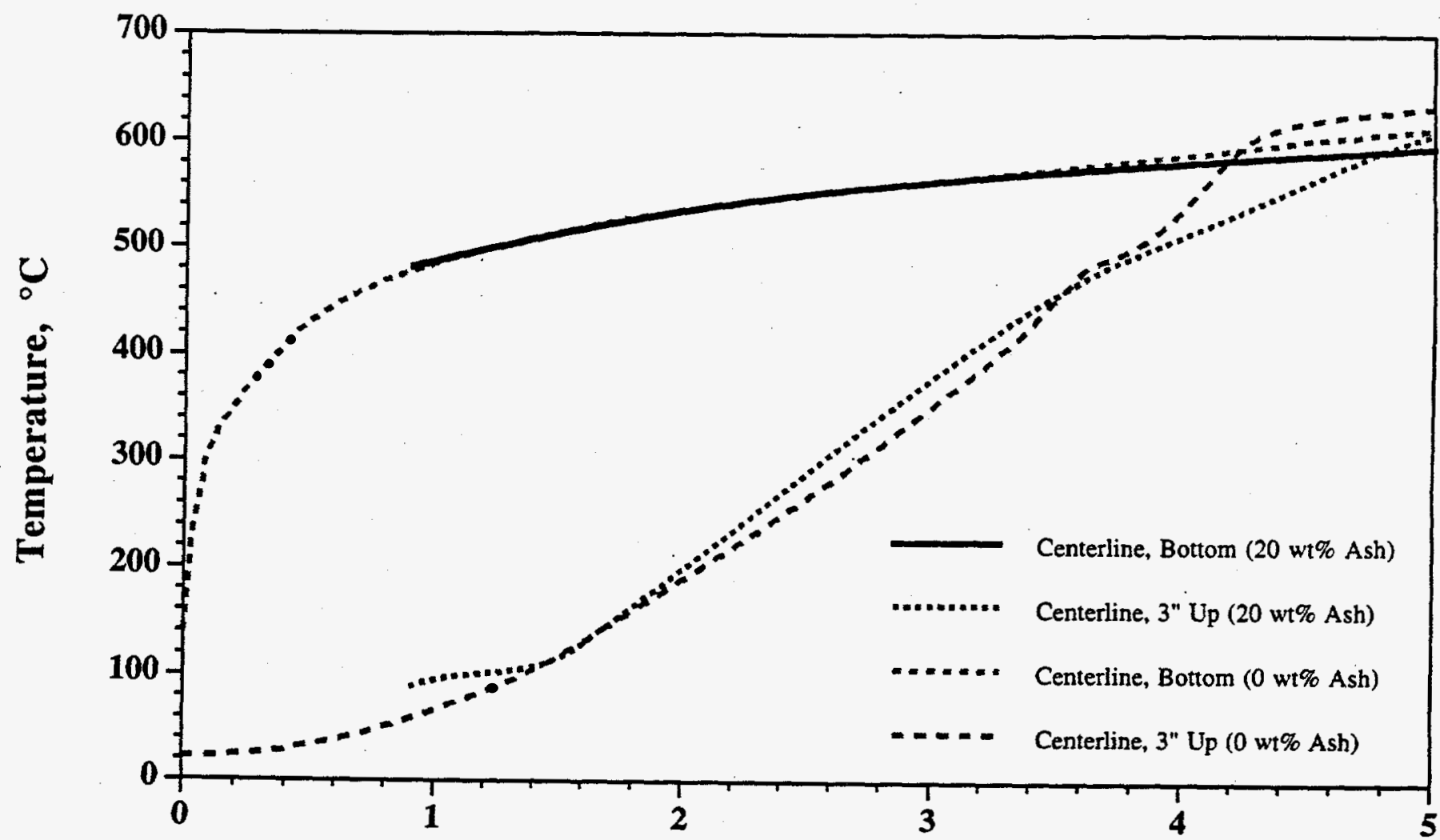

Run Time, Hours

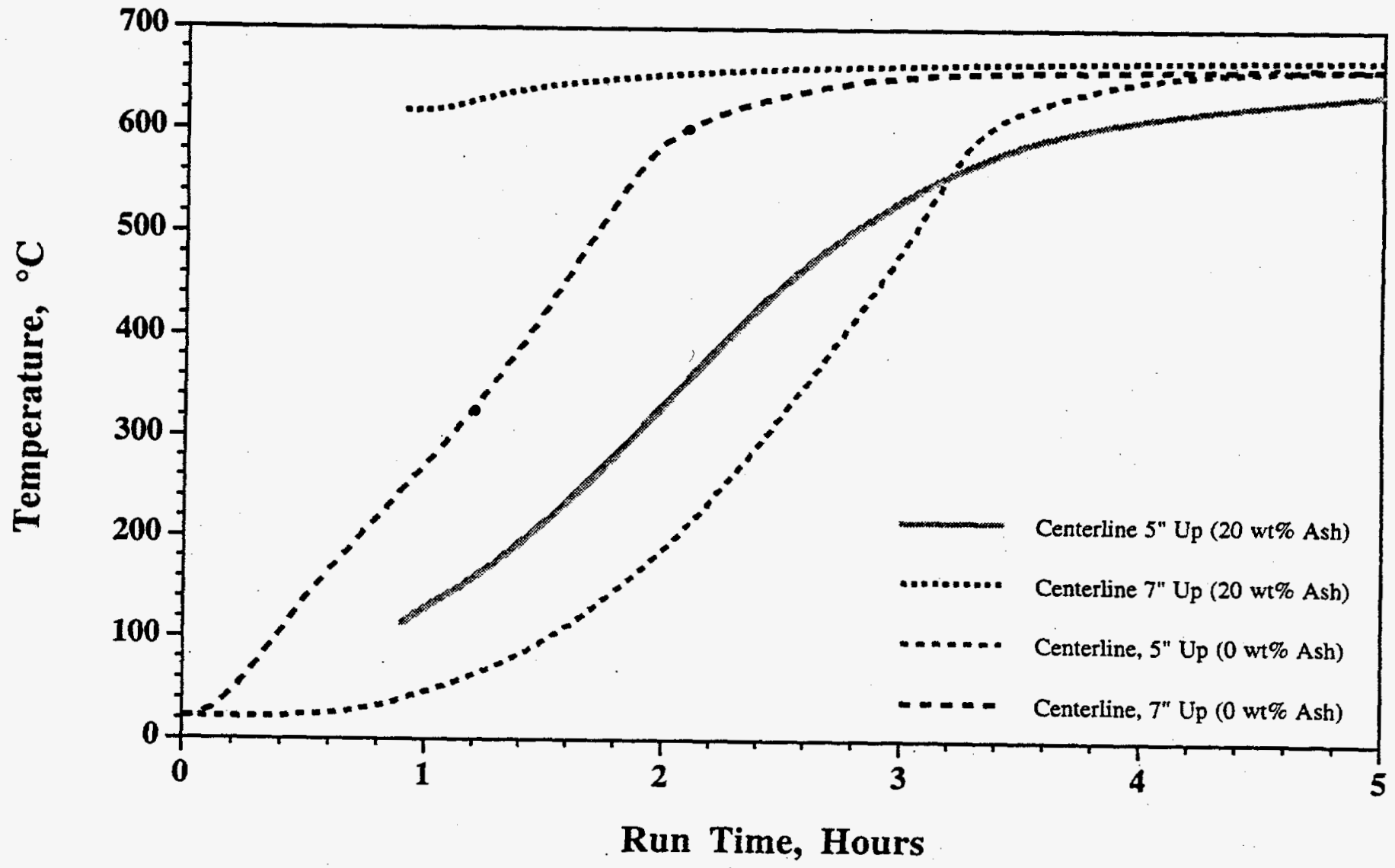


TEMPERA'TURE PROFILES FOR VOLLRATH CONTAINER PNNL BIACK FRIT WITH DIFFERENT ASH LOADING

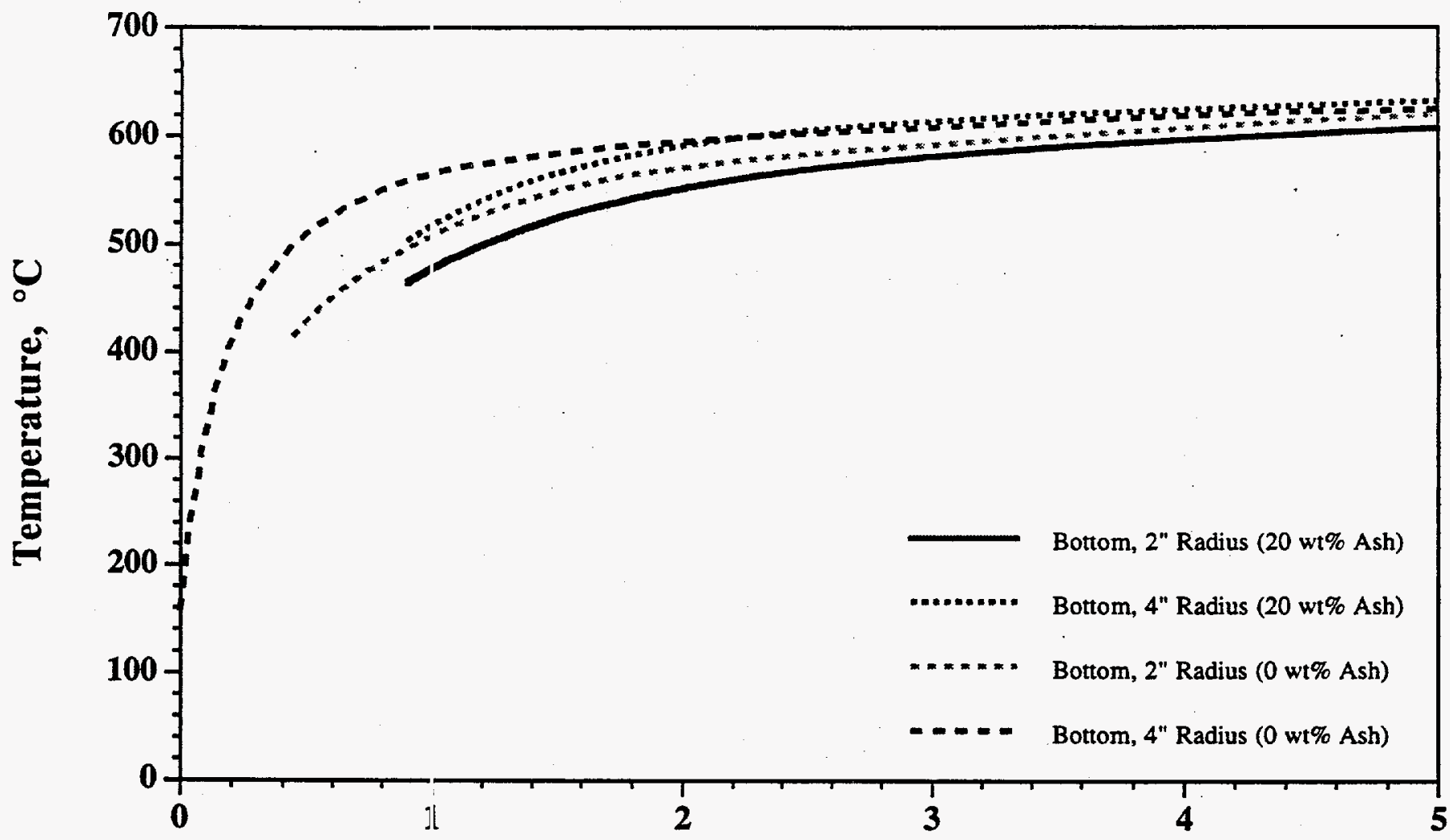

Run Time, Hours

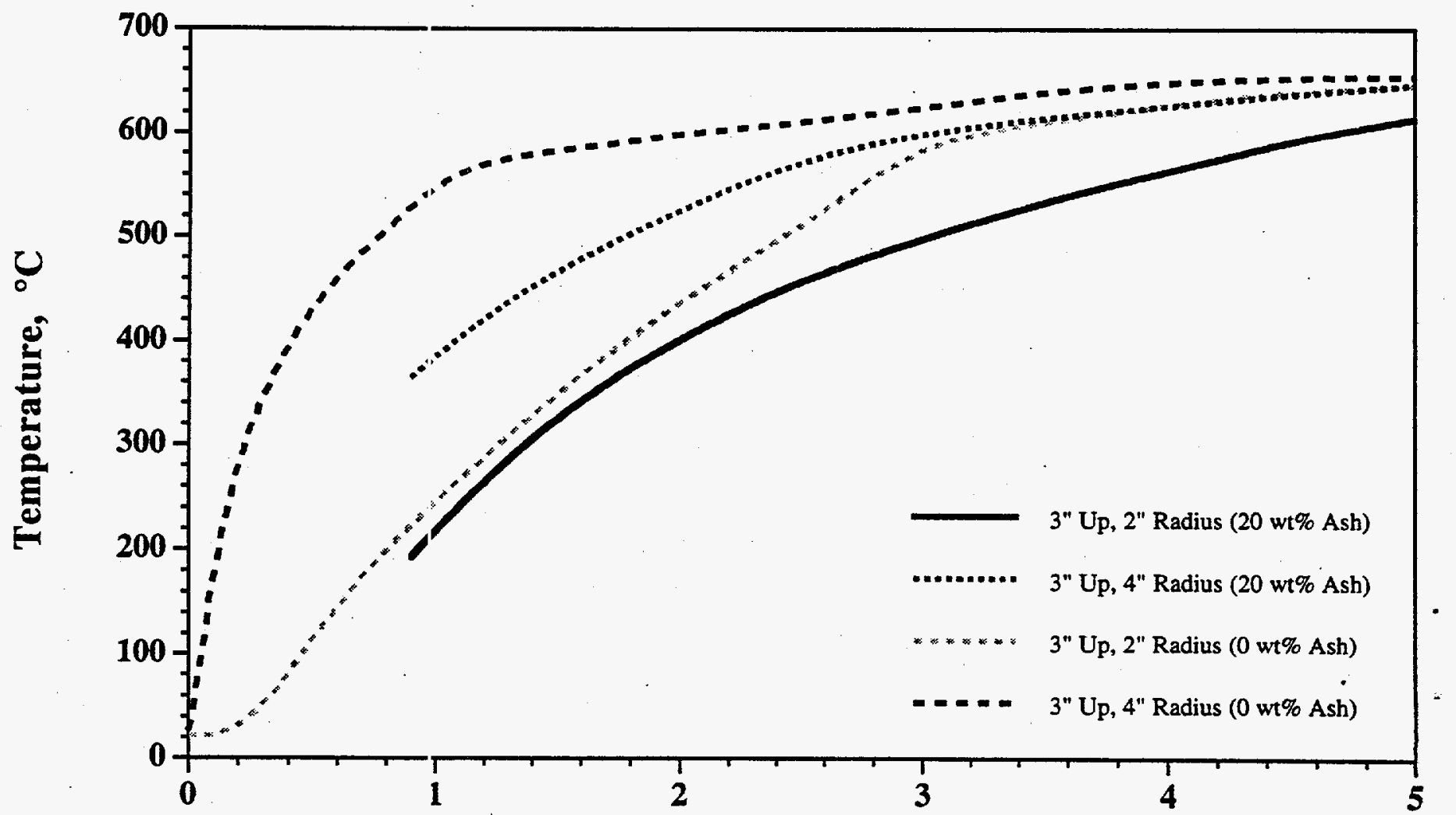

Run Time, Hours 